\title{
Nitro-Oleic Acid Attenuates OGD/R- Triggered Apoptosis in Renal Tubular Cells via Inhibition of Bax Mitochondrial Translocation in a PPAR- $\gamma$-Dependent Manner
}

\author{
Huibin Nie Xia Xue $^{\mathrm{b}}$ Jie Lic Xiangchun Liu ${ }^{\mathrm{a}}$ Shasha Lva Guangju Guan ${ }^{\mathrm{a}}$ \\ Haiying Liu ${ }^{a}$ Gang Liu ${ }^{a}$ Shanshan Liu ${ }^{a}$ Zhixin Chen ${ }^{a}$ \\ a Nephrology Research Institute of Shandong University, The Second Hospital of Shandong University, \\ Shandong University, Jinan, 'bepartment of Pharmacy, The Second Hospital of Shandong University, \\ Jinan, 'Department of Otolaryngology, Shengli Oilfield Central Hospital, Dongying, Shandong, China
}

\section{Key Words}

OGD/R • Apoptosis • Mitochondria • Bax • Nitro-oleic Acid

\begin{abstract}
Background: Nitroalkene derivatives of oleic acid $\left(\mathrm{OA}-\mathrm{NO}_{2}\right)$ serve as high-affinity ligand for PPAR- $\gamma$, which regulates apoptosis, oxidation and inflammation and plays a central role in ischemia-reperfusion injury. In the present study, we elucidated the protective mechanisms of $\mathrm{OA}-\mathrm{NO}_{2}$ against renal ischemia-reperfusion injury. Methods: HK-2 cells were subjected to oxygen and glucose deprivation followed by re-oxygenation (OGD/R) to mimic renal ischemia-reperfusion injury. Cell apoptosis was analyzed by flow cytometry. Bax mitochondrial translocation, cytochrome $c$ and apoptosis-inducing factor (AIF) cytosolic leakage and Akt/ Gsk $3 \beta$ phosphorylation were evaluated by Western blotting. Bax activation was visualized by immunocytochemistry. GW9662 and siRNA transfection were employed to examine the involvement of PPAR- $\gamma$. Results: OGD/R injury promoted mitochondrial translocation and activation of Bax, leakage of cytochrome $\mathrm{c}$ and AIF, subsequent caspase-3 activation, and eventually cell apoptosis. Pre-incubation with $\mathrm{OA}-\mathrm{NO}_{2}(1.25 \mu \mathrm{M}, 45 \mathrm{~min})$ inhibited Bax activation and blocked apoptotic cascade, while the protective effects were negated by GW9662 or PPAR- $\gamma$ siRNA. Moreover, OA-NO $\mathrm{N}_{2}$ restored Akt and Gsk $3 \beta$ phosphorylation in a PPAR- $\gamma-$ dependent way. Conclusion: These findings suggest that $\mathrm{OA}-\mathrm{NO}_{2}$ attenuates OGD/R-induced apoptosis by inhibiting Bax translocation and activation and the subsequent mitochondriadependent apoptotic cascade in a PPAR- $\gamma$ dependent manner.
\end{abstract}




\section{Cellular Physiology and Biochemistry}

Cell Physiol Biochem 2015;35:1201-1218

\begin{tabular}{l|l}
\hline DOI: $10.1159 / 000373944$ & (C) 2015 S. Karger AG, Basel
\end{tabular}

\begin{tabular}{l|l} 
Published onlıne: February 10, 2015 & www.karger.com/cpb
\end{tabular}

Nie et al.: OA-NO $\mathrm{N}_{2}$ Inhibits Apoptosis via PPAR- $\gamma$

\section{Introduction}

Renal ischemia-reperfusion(I/R) injury, which occurs in many clinical settings including renal transplantation, shock, and vascular surgery, is a major cause of acute renal failure. A number of pathologic processes contribute to renal I/R injury, including reduced renal blood flow; tubular obstruction induced by detached epithelium, infiltrated leukocytes and aggregated platelets [1,2]; activation of pro-inflammatory cytokines, reactive nitrogen species (RNS) and reactive oxygen species (ROS) [2, 3]. These inter-related events cause renal cell injury and lead to eventual cell death. Activation of the apoptotic cell death cascade has been reported to play a key role in post-ischemic tissue damage and organ dysfunction; thus inhibition of apoptosis can ameliorate renal ischemia-reperfusion injury $[4,5]$.

Peroxisome proliferator-activated receptor $\gamma$ (PPAR- $\gamma$ ) has emerged as a novel therapeutic target in a wide range of pathologies elicited by ischemia and reperfusion, such as myocardial infarction, ischemic stroke and acute kidney injury. The protective role of PPAR- $\gamma$ in I/R injury is suggested by data showing that heterozygous PPAR- $\gamma$-deficient mice subjected to intestinal I/R suffer more pronounced injury than wild-type control mice [6] and that the PPAR- $\gamma$ agonist, rosiglitazone, is able to control cell apoptosis and contribute to tissue protection [7-9]. Therefore, agents that regulate PPAR- $\gamma$ activation are being actively pursued.

Nitrated unsaturated fatty acids $\left(\mathrm{NO}_{2}-\mathrm{FA}\right)$ are derived from nitric oxide (NO) and $\mathrm{NO}_{2}^{-}$ dependent redox reactions with unsaturated fatty acids, including nitro-oleic acid (OA$\mathrm{NO}_{2}$ ) and nitro-linoleic acid $\left(\mathrm{LNO}_{2}\right)$ [10]. They mediate a broad range of anti-inflammatory, anti-oxidative and vascular-protective actions. $\mathrm{NO}_{2}$-FA suppress pro-inflammatory gene expression and neutrophil infiltration by either direct nitroalkylation of the nuclear factor $\kappa \mathrm{B}(\mathrm{NF} \kappa \mathrm{B})$ p65 subunit or inhibition of pro-inflammatory STAT signaling [11-13]. They exert vascular protection by up-regulating HO-1 and endothelial nitric oxide synthase (eNOS) expression in pulmonary epithelium and aortic endothelial cells [14-16]. $\mathrm{NO}_{2}$-FA also activate heat shock factor (HSF) and nuclear factor-E2-related factor 2(Nrf2), mediators of antioxidant and phase II detoxifying enzymes [17]. Notably, $\mathrm{NO}_{2}$-FA have been found to be robust endogenous activating ligands for all three PPARs, exhibiting the greatest potency as PPAR- $\gamma$ agonists [18-20]. They possess a number of PPAR- $\gamma$-dependent effects, including promoting adipogenesis in 3T3-L1 pre-adipocytes, inducing CD36 receptor expression in macrophages $[18,19]$ and inhibiting NF- $\kappa B$ activation in inflammatory disease $[12,21,22]$.

The evidence to date suggests that $\mathrm{NO}_{2}$-FA could reduce cardiac infarct size and enhance cell vitality of cardiomyocytes after ischemia-reperfusion injury both in vivo and in vitro [23]. We previously showed that $\mathrm{OA}-\mathrm{NO}_{2}$ attenuated functional and histological indices in a mouse model of renal I/R injury [24]. These results suggested protective effects of $\mathrm{NO}_{2}$-FA against ischemia-reperfusion injury. However, it is unclear whether $\mathrm{NO}_{2}$-FA can alleviate renal I/R injury via directly regulating cell apoptotic signaling. Therefore, we evaluated whether OA$\mathrm{NO}_{2}$ could protect renal tubular cells from mitochondria-mediated apoptosis triggered by combined oxygen and glucose deprivation/re-oxygenation (OGD/R), a widely used in vitro model of I/R injury, and determined whether the mechanism was PPAR- $\gamma$-dependent.

\section{Materials and Methods}

Cell culture and $O G D / R$ protocol, cell treatments

Normal human kidney epithelial (HK-2) cells (CCTCC, Wuhan, China) were maintained in Dulbecco's modified Eagle's medium (DMEM) (Hyclone, NY, USA) supplemented with $10 \%$ (v/v) fetal bovine serum (FBS) (Gibco, NY, USA), $4 \mathrm{mM}$ glutamine, $100 \mathrm{IU} \cdot \mathrm{mL}^{-1}$ penicillin / streptomycin. One day before the assays, $5 * 10^{3}$ or $2 * 10^{5}$ cells per well were plated into 96 or 6 -well tissue culture plates and cultured at $37^{\circ} \mathrm{C}$ in a humidified atmosphere with $5 \% \mathrm{CO}_{2}$.

The OGD/R protocol was performed as previously described [25-28] with a slight modification. Confluent HK-2 cells were made quiescent by serum deprivation for 24 hours and then cultured for 


\section{Cellular Physiology and Biochemistry}

Cell Physiol Biochem 2015;35:1201-1218

DOI: $10.1159 / 000373944$

Published onlıne: February 10, 2015

2015 S. Karger AG, Basel

www.karger.com/cpb

Nie et al.: $\mathrm{OA}-\mathrm{NO}_{2}$ Inhibits Apoptosis via PPAR- $\gamma$

the indicated periods of time in DMEM containing no glucose (M\&C GENE, Beijing, China) in a hermetic incubator (Hitech biotechnology, Guangzhou, China) with an anaerobic environment $\left(85 \% \mathrm{~N}_{2}, 10 \% \mathrm{H}_{2}\right.$, $5 \% \mathrm{CO}_{2}$ ). Re-oxygenation was performed in complete medium containing $5.5 \mathrm{mM}$ glucose and a humidified atmosphere with $5 \% \mathrm{CO}_{2}$ at $37^{\circ} \mathrm{C}$. Cells maintained at normal culture condition (complete culture medium, $5 \% \mathrm{CO}_{2}$ atmosphere, $37^{\circ} \mathrm{C}$ ) with or without ethanol and/or dimethyl sulfoxide (DMSO) treatment served as controls.(Fig. 1A)

In the pre-treatment assays, cells were treated with $\mathrm{OA}-\mathrm{NO}_{2}$ (Cayman chemical, Ann Arbor, USA) or oleic acid (OA) (Sigma-Aldrich, St. Louis, USA) dissolved in ethanol for $45 \mathrm{~min}$ and GW9662 (Sigma-Aldrich, St. Louis, USA), a PPAR- $\gamma$ inhibitor, dissolved in DMSO for $1 \mathrm{~h}$ before the OGD/R injury and persisted for the whole process of OGD/R $[18,19]$. The final concentration of ethanol and DMSO did not exceed $0.1 \%(\mathrm{v} / \mathrm{v})$. $\mathrm{OA}-\mathrm{NO}_{2}$ used in the study was an equimolar distribution of 9- and 10-nitro-octadeca- 9-enoic acid [17].

CCK-8 assay

Cell viability was determined with a cell counting kit (CCK)-8 (Dojindo Laboratories, Kumamoto, Japan), following the manufacturer's instructions. The absorbance was measured at $450 \mathrm{~nm}$ using the MULTISKAN MK3 spectrophotometer (Thermo scientific, NY, USA).

Flow cytometry analysis of apoptosis

Cell apoptosis was measured with Annexin V-FITC (Roche Diagnostics, Mannheim, Germany) and 7-AAD (ebio-science, San Diego, USA) in un-transfected cells, and PE Annexin V Apoptosis Detection Kit I (BD Biosciences, San Jose, USA) was used to detect cell apoptosis in PPAR- $\gamma$ siRNA/control siRNA transfected cells. According to the manufacturer's instructions, cells were incubated with $100 \mu \mathrm{L}$ binding buffer containing $5 \mu \mathrm{L}$ Annexin $V$ and $5 \mu \mathrm{L}$ 7-AAD in the dark for $15 \mathrm{~min}$ at room temperature. Cell apoptosis was analyzed on a FACS Calibur flow cytometer (BD Biosciences, San Jose, USA).

\section{Hoechst staining}

After stress, HK-2 cells were fixed with 4\% paraformaldehyde for $30 \mathrm{~min}$ at room temperature, and then incubated with Hoechst $33342\left(5 \mu \mathrm{g} \cdot \mathrm{mL}^{-1}\right.$, AMRESCO, Solon, $\left.\mathrm{OH}, \mathrm{USA}\right)$ at $37^{\circ} \mathrm{C}$ for $20 \mathrm{~min}$. Fluorescentlabelled incisive cells were photographed with a Leica fluorescence microscope.

\section{Immunocytochemistry}

After transfection and/or stress, cells were fixed with 4\% paraformaldehyde for $30 \mathrm{~min}$, permeabilized with $0.3 \%$ Triton X-100 for $5 \mathrm{~min}$, blocked with 5\% BSA in PBS for $1 \mathrm{~h}$ at room temperature and then incubated for $20 \mathrm{~h}$ at $4^{\circ} \mathrm{C}$ with 6A7 Bax monoclonal antibody [29] (1:200, Alexis Biochemicals, San Diego, USA) diluted in PBS. After incubation, the cells were washed three times with PBS and incubated with Rhodamine (TRITC)-conjugated secondary antibody (ZSGB, Beijing, China) for $1 \mathrm{~h}$ at $37^{\circ} \mathrm{C}$. After being stained with DAPI for 5 min at room temperature, cells were adhered to glass slides in anti-fade mounting medium (Beyotime, Shanghai, China). For detection of Bax co-localization with mitochondria, cells were incubated with Mito-tracker Green (500 nM) (Beyotime, Shanghai, China) for $30 \mathrm{~min}$ at $37^{\circ} \mathrm{C}$. Cells were then fixed and exposed to 6A7 monoclonal antibody, and routine immunocytochemistry was performed. Fluorescent images were captured using Leica fluorescence microscopy. Quantitation of active Bax immunoreactivity was performed by determining the percentage of $\mathrm{HK}-2$ cells that showed positive punctate staining with the 6A7 monoclonal antibody.

\section{Subcellular fractionation and Western blotting analysis}

After transfection and/or stress, whole cell lysates of HK-2 cells were obtained using total protein extraction kit (DBI Bioscience, Ludwigshafen, Germany) according to the manufacturer's instructions, and the protein concentration was quantified using the Bradford method (Beyotime, Shanghai, China). The samples were separated in 12\% SDS-polyacrylamide gels, transferred onto polyvinylidene difluoride membranes (Millipore, MA, USA) and incubated overnight at $4{ }^{\circ} \mathrm{C}$ with primary antibodies. After incubation with horseradish peroxidase-conjugated secondary antibody (1:5000, ZSGB, Beijing, China) for $2 \mathrm{~h}$ at room temperature in 5\% skimmed milk/TBST, proteins were detected by enhanced chemiluminescence (Millipore, MA, USA). Primary antibodies used in this study were: rabbit polyclonal antibody to PARP, caspase-3, Cleaved caspase-3, Bcl-2, Akt, Ser473-phospho-Akt (1:1000; CST, Boston, USA); PPAR- $\gamma$ (1:500; Santa Cruz 


\section{Cellular Physiology and Biochemistry}

Cell Physiol Biochem 2015;35:1201-1218

\begin{tabular}{l|l}
\hline DOI: 10.1159/000373944 & (C) 2015 S. Karger AG, Basel
\end{tabular}

Published onlıne: February 10, $2015 \quad$ www.karger.com/cpb

Nie et al.: OA-NO ${ }_{2}$ Inhibits Apoptosis via PPAR- $\gamma$

Fig. 1. Oxygen and glucose deprivation/re-oxygenation (OGD/R) gradually decreased viability in HK-2 cells. A: Confluent HK-2 cells were subjected to oxygen-glucose deprivation (OGD) with or without $\mathrm{OA}-\mathrm{NO}_{2}$ pretreatment for the indicated period of time to mimic ischemia. Reperfusion injury was imitated by resupplying glucose and oxygen for $24 \mathrm{~h}$. B: Confluent HK-2 cells were subjected to OGD for $8 \mathrm{~h}, 16 \mathrm{~h}$ or $24 \mathrm{~h}$ followed by 24h-recovery with or without OA$\mathrm{NO}_{2}(1.25 \mu \mathrm{M})$ pretreatment. Viability was determined by CCK-8 assay. Each assay was representative of three independent experiments. Data were shown as means \pm SEM; ${ }^{*} \mathrm{p}<0.05,{ }^{* *} \mathrm{p}<0.01$ and $* * * \mathrm{p}<0.001$.

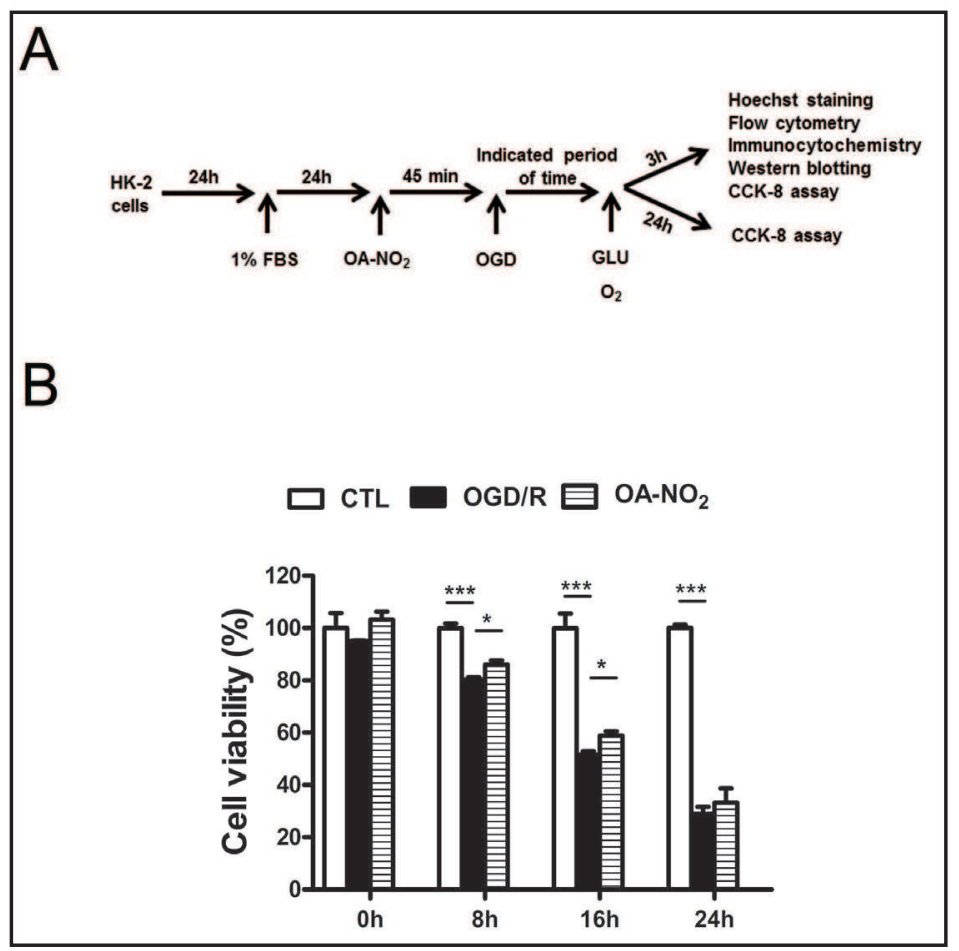

Biotechnology, Dallas, USA ); Bax (1:1000; Abcam, Cambridge, UK ); cytochrome c (1:400; immunoway, Newark, USA); AIF (1:1000, proteintech, Chicago, USA); $\beta$-actin (1:800; Bioworld, Minnesota, USA); rabbit

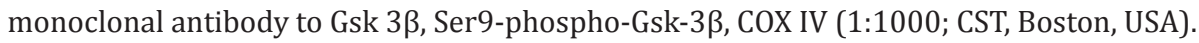

In some experiments, fractionation of the cell lysates into cytosolic and mitochondrial fractions was performed using a mitochondria isolation kit (Beyotime, Shanghai, China) according to the manufacturer's instructions before the Western blotting.

\section{RNAi transfection}

For transfection, the fifth or sixth passage HK-2 cells were planted at a concentration of 4-5 × $10^{4}$ / $\mathrm{ml}$. When they reached $30 \%-50 \%$ confluence, the media was replaced with enhanced infection solution (Genechem, Shanghai, China) supplemented with recombinant lentivirus containing PPAR- $\gamma$ siRNA (CAACAGACAAATCACCATT) or control siRNA (TTCTCCGAACGTGTCACGT) (Genechem, Shanghai, China) at a multiplicity of infection (MOI) of 50 . After $10 \mathrm{~h}$ transfection, the media was replaced with common media. After being cultured for another $120 \mathrm{~h}$ in complete medium, cells were harvested to evaluate the protein contents of PPAR- $\gamma$.

Statistical analysis

Data were presented as means \pm SEM. Comparisons of results were performed with Student's t-test or one-way ANOVA followed by Dunnett's Multiple Comparison Test. $\mathrm{p}<0.05$ was considered statistically significant. SPSS 17.0 was used for all calculations.

\section{Results}

Oxygen and glucose deprivation/re-oxygenation (OGD/R) gradually decreased viability in HK-2 cells

HK-2 cells were subjected to combined deprivation of oxygen and glucose for $8 \mathrm{~h}, 16$ $\mathrm{h}$ or $24 \mathrm{~h}$ followed by a re-oxygenation period of $24 \mathrm{~h}$ to mimic renal ischemia-reperfusion injury in vitro (Fig. 1A). The cell viability gradually declined as the OGD time was prolonged. The survival rates were $80.27 \pm 0.96 \%, 51.62 \pm 1.37 \%$ and $29 \pm 2.69 \%$ after $8 \mathrm{~h}, 16 \mathrm{~h}$ or $24 \mathrm{~h}$ of OGD followed by $24 \mathrm{~h}$ of re-oxygenation, respectively (Fig. 1B). 
A
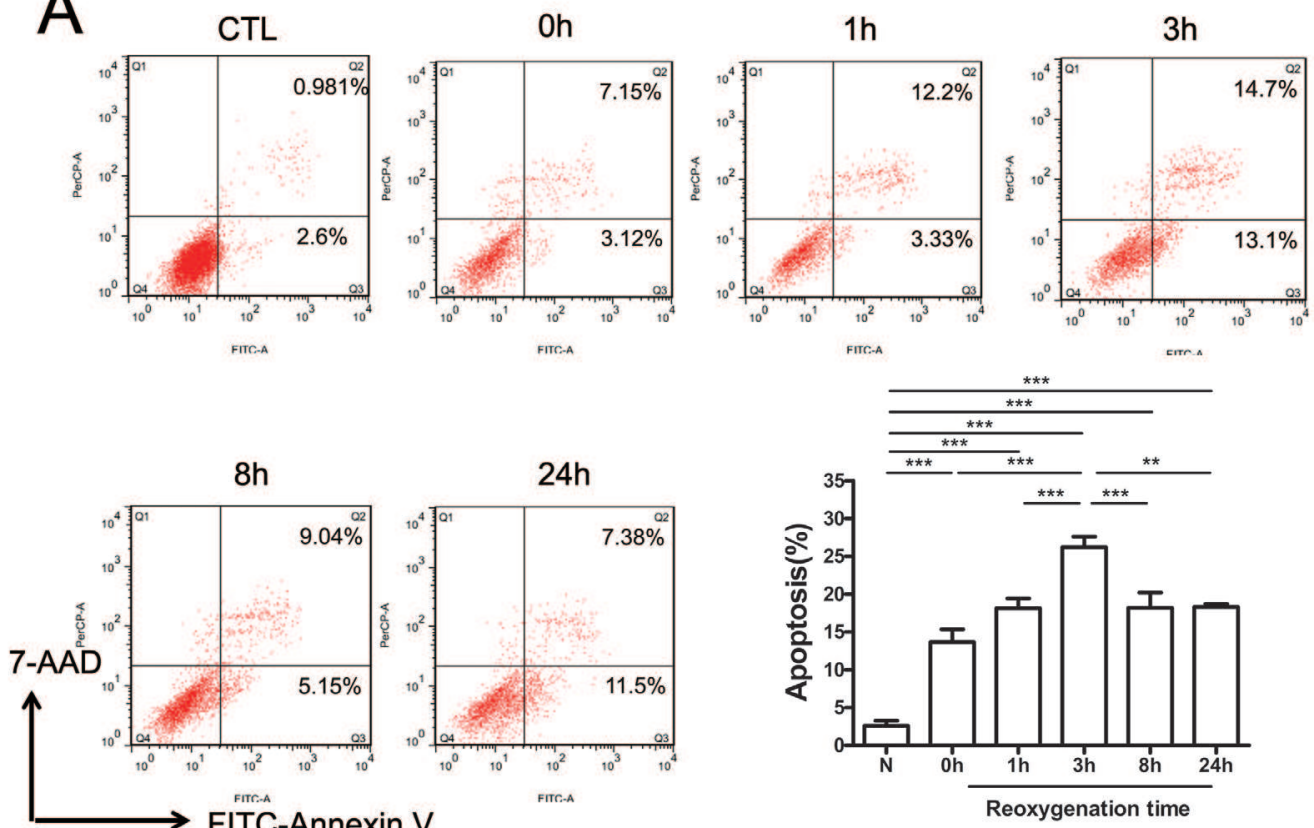

FITC-Annexin V

B
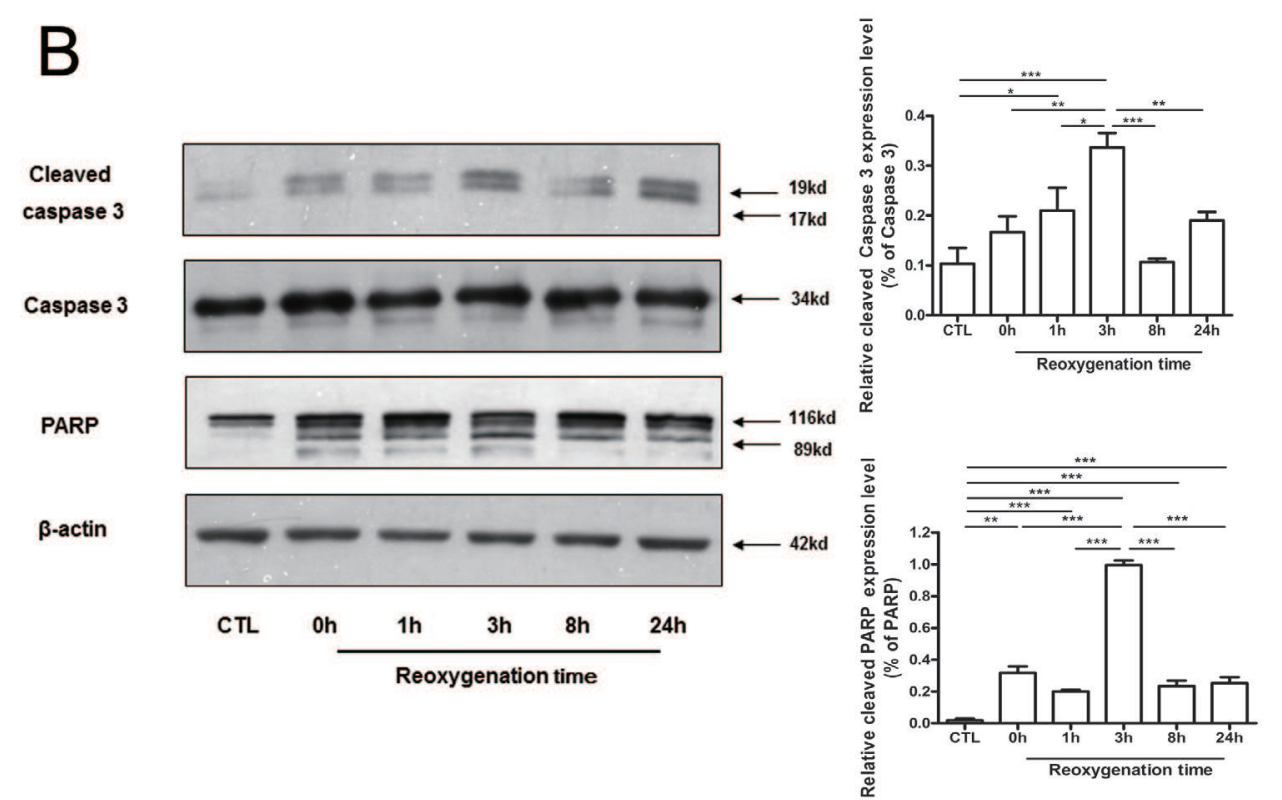

Fig. 2. OGD/R induced cell apoptosis. Confluent HK-2 cells were subjected to OGD for $16 \mathrm{~h}$ followed by an aerobic recovery period of $0 \mathrm{~h}, 1 \mathrm{~h}, 3 \mathrm{~h}, 8 \mathrm{~h}$, or $24 \mathrm{~h}$, respectively. A: Apoptotic cells were analyzed by flow cytometry. B: Cleaved caspase-3 and PARP expressions were examined by western blotting. Each assay was representative of three independent experiments. Data were shown as means \pm SEM; ${ }^{*} p<0.05,{ }^{* *} p<0.01$ and ${ }^{* * *} \mathrm{p}<0.001$.

Apoptosis of HK-2 cells was then analyzed by flow cytometry after $16 \mathrm{~h}$ of OGD followed by $0 \mathrm{~h}, 1 \mathrm{~h}, 3 \mathrm{~h}, 8 \mathrm{~h}$ and $24 \mathrm{~h}$ of re-oxygenation. The apoptotic rate was only $13.67 \pm 1.70 \%$ without re-oxygenation, but increased in the following hours and peaked at $26.2 \pm 1.42 \%$ 


\section{A}
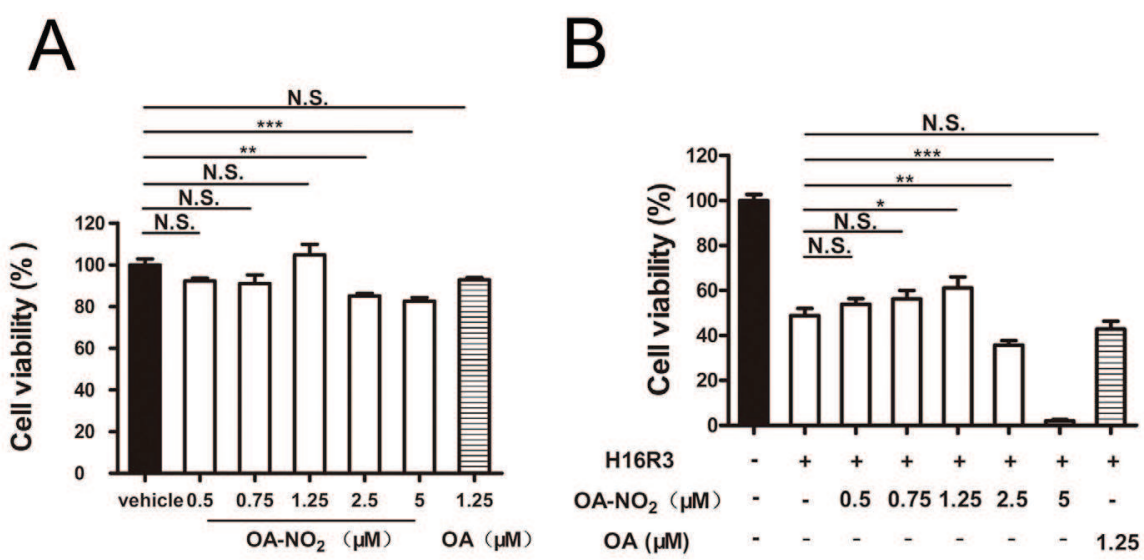

Fig. 3. $\mathrm{OA}-\mathrm{NO}_{2}$ but not $\mathrm{OA}$ improved cell viability after OGD/R injury. A: Confluent HK-2 cells were treated with $\mathrm{OA}-\mathrm{NO}_{2}(0.5-5 \mu \mathrm{M})$ or $\mathrm{OA}(1.25 \mu \mathrm{M})$ for $20 \mathrm{~h}$. Cytotoxicity of $\mathrm{OA}-\mathrm{NO}_{2}$ was determined by CCK-8 assay. B: Confluent HK-2 cells were subjected to OGD for $16 \mathrm{~h}$ followed by $3 \mathrm{~h}$ re-oxygenation period (H16R3) with or without $\mathrm{OA}-\mathrm{NO}_{2}(0.5-5 \mu \mathrm{M})$ or $\mathrm{OA}(1.25 \mu \mathrm{M})$ pretreatment. Viability was determined by CCK-8 assay. Each assay was representative of three independent experiments. Data were shown as means $\pm \mathrm{SEM}$; $\mathrm{p}<0.05$, ${ }^{* *} \mathrm{p}<0.01$ and ${ }^{* * *} \mathrm{p}<0.001$, N.S. meant no significance.

at $3 \mathrm{~h}$ of re-oxygenation. The rate subsequently declined to $18.20 \pm 2.00 \%$, and remained at $18.31 \pm 0.40 \%$ by the end of the $24 \mathrm{~h}$-long recovery (Fig. $2 \mathrm{~A}$ ).

The time course of active caspase- 3 and cleaved PARP during reperfusion was further investigated (Fig. 2B). Cleaved caspase-3 appeared instantly after OGD injury, reached peak levels by $3 \mathrm{~h}$ of re-oxygenation and was detectable for several hours afterwards. Accordingly, the expression of $89 \mathrm{kDa}$ PARP fragment followed a profile similar to that of the cleaved caspase-3.

Overall, these data indicated that cell viability declined as duration of OGD increased and cell apoptosis occurred during the whole re-oxygenation period, peaking at $3 \mathrm{~h}$. Thus 16 $\mathrm{h}$ of OGD followed by $3 \mathrm{~h}$ of re-oxygenation was selected as the standard assay condition for studying the OGD/R-induced apoptosis.

\section{$\mathrm{OA}-\mathrm{NO}_{2}$ but not $\mathrm{OA}$ improved cell viability after OGD/R injury}

The CCK-8 assay showed that proliferation was significantly inhibited in HK-2 cells treated with $\mathrm{OA}-\mathrm{NO}_{2}(2.5$ or $5 \mu \mathrm{M})$, but was not affected at lower concentrations $(0.5,0.75$ or $1.25 \mu \mathrm{M})$ (Fig. 3A).

Pretreatment with $\mathrm{OA}-\mathrm{NO}_{2}(1.25 \mu \mathrm{M})$ for 45 min dramatically increased cell viability from $48.88 \pm 3.13 \%$ to $61.17 \pm 4.90 \%(\mathrm{p}<0.05)$ after $16 \mathrm{~h}-\mathrm{OGD}$ followed by 3 h-re-oxygenation. In contrast, the native fatty acid precursor of $\mathrm{OA}-\mathrm{NO}_{2}$, oleic acid (OA), did not show a protective effect (Fig. 3B).

This finding suggested that the protective effect of $\mathrm{OA}-\mathrm{NO}_{2}$ in $\mathrm{OGD} / \mathrm{R}$ injury was attributable to the nitration of the fatty acid. Based on this, we selected $\mathrm{OA}-\mathrm{NO}_{2}(1.25 \mu \mathrm{M})$ to examine its protective effect in the following assays.

\section{$\mathrm{OA}-\mathrm{NO}_{2}$ protected HK-2 cells against OGD/R-induced apoptosis}

The potential for $\mathrm{OA}-\mathrm{NO}_{2}$ to protect against OGD/R-induced apoptosis was tested with flow cytometry. Pretreatment with $\mathrm{OA}-\mathrm{NO}_{2}$ for 45 min reduced cell apoptosis from $27.11 \pm 1.29 \%$ to $9.73 \pm 0.59 \%(p<0.001)$ after $16 \mathrm{~h}-\mathrm{OGD}$ followed by 3 h-re-oxygenation (Fig. $4 \mathrm{~A})$.

The nuclei morphology was also visualized by Hoechst 33342 staining. Under normoxia, the nuclei appeared relatively large and faintly stained. After 16h-OGD followed by 3h-reoxygenation, the nuclei appeared to be condensed, fragmented or heterogeneous. $\mathrm{OA}-\mathrm{NO}_{2}$ restored the nuclei shape after OGD/R injury (Fig. 4B). 


\section{A}
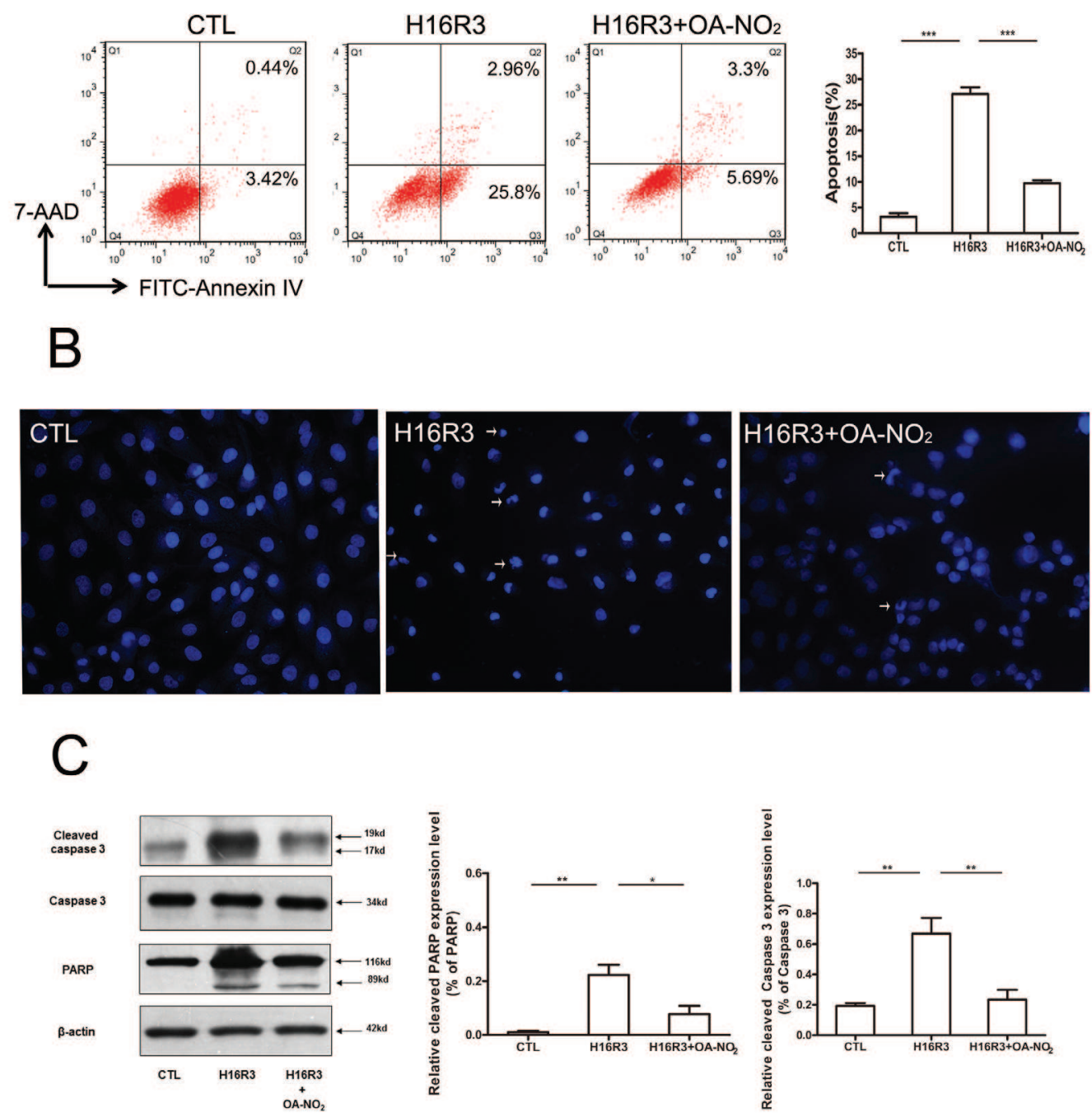

Fig. 4. OA-NO $\mathrm{NO}_{2}$ protected HK-2 cells against OGD/R-induced apoptosis. Confluent HK-2 cells were subjected to OGD for $16 \mathrm{~h}$ followed by $3 \mathrm{~h}$ re-oxygenation period (H16R3) with or without $\mathrm{OA}-\mathrm{NO}_{2}(1.25 \mu \mathrm{M})$ pretreatment. A: Apoptotic cells were analyzed by flow cytometry. B: Nuclei morphological changes were visualized by Hoechst 33342 staining. The arrows indicated the condensed or fragmented nuclei. Magnification: $\mathrm{x}$ 200. C: Cleaved caspase- 3 and PARP expressions were examined by western blotting. Each assay was representative of three independent experiments. Data were shown as means $\pm S E M ;{ }^{*} \mathrm{p}<0.05,{ }^{* *} \mathrm{p}<0.01$ and $* * * \mathrm{p}<0.001$, N.S. meant no significance.

In accordance with the results of flow cytometry and Hoechst staining, Western blotting showed that $\mathrm{OA}-\mathrm{NO}_{2}$ reduced the expression of cleaved caspase- 3 and cleaved PARP induced by $16 \mathrm{~h}$-OGD and 3h-re-oxygenation (Fig. 4C). Above all, these results indicated that $\mathrm{OA}-\mathrm{NO}_{2}$ could exert its renal protection via inhibiting apoptosis induced by OGD/R injury.

$\mathrm{OA}-\mathrm{NO}_{2}$ inhibited OGD/R-induced Bax translocation, activation and subsequent Mitochondrial Outer Membrane Permeabilization (MOMP)

Bax is a key pro-apoptotic factor. It permeabilizes the mitochondrial outer membrane and induces leakage of cytochrome $\mathrm{c}$ and AIF into the cytosol upon activation [30]. Here, 


\section{Cellular Physiology and Biochemistry}

Cell Physiol Biochem 2015;35:1201-1218

ublished online: February 10, 2015

Nie et al:: OA-NO $\mathrm{N}_{2}$ Inhibits Apoptosis via PPAR- $\gamma$

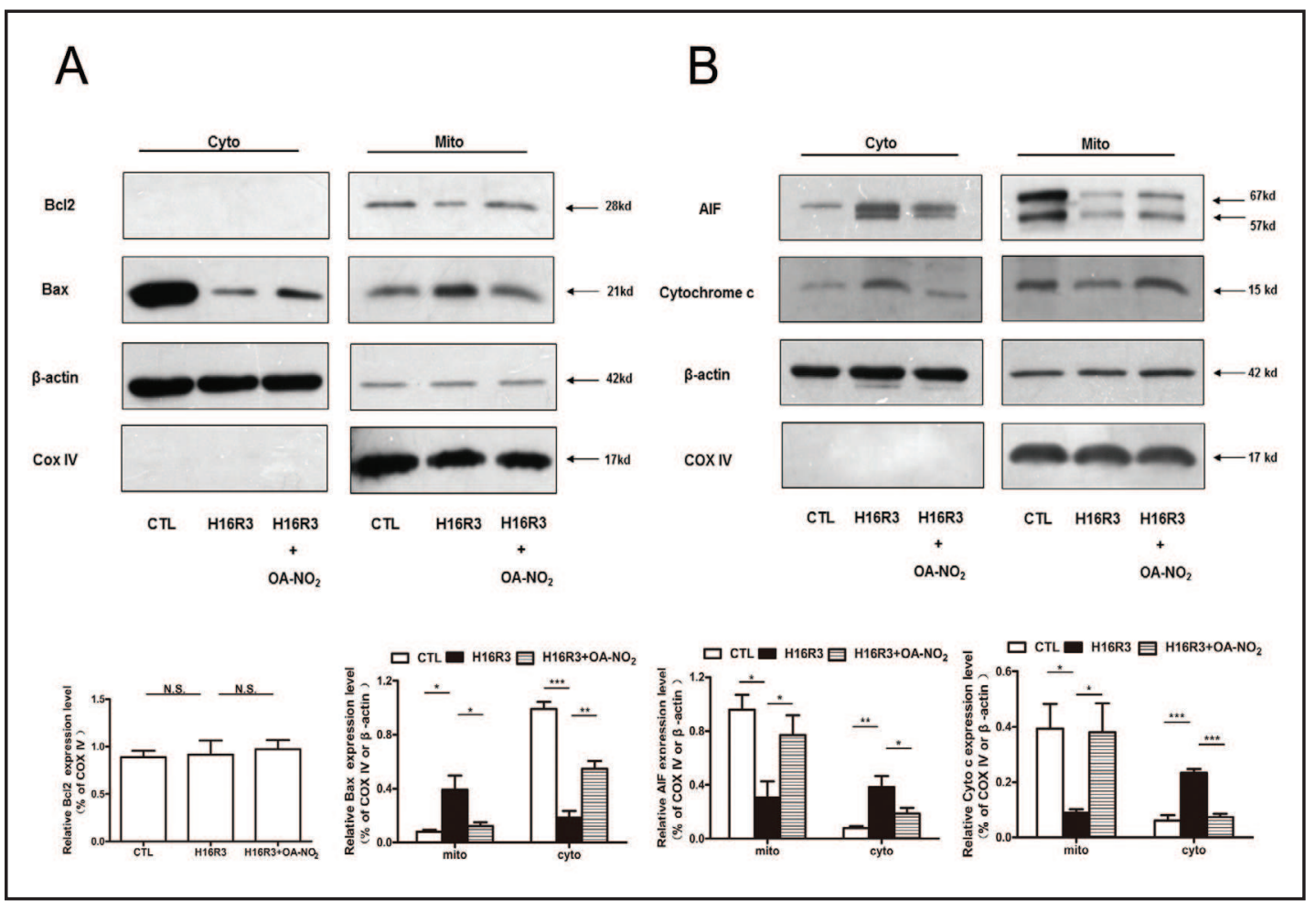

Fig. 5. $\mathrm{OA}-\mathrm{NO}_{2}$ inhibited OGD/R induced Bax translocation and subsequent Mitochondrial Outer Membrane Permeabilization (MOMP). Confluent HK-2 cells were subjected to OGD for $16 \mathrm{~h}$ followed by $3 \mathrm{~h}$ re-oxygenation period (H16R3) with or without $\mathrm{OA}-\mathrm{NO}_{2}(1.25 \mu \mathrm{M})$ pretreatment. Expressions of Bax, Bcl-2, cytochrome $\mathrm{c}$ and AIF in mitochondrial (Mito) and cytosolic (Cyto) fractions were examined by western blotting. Each assay was representative of three independent experiments. Data were shown as means $\pm \mathrm{SEM}$; $\mathrm{p}<0.05$, ${ }^{* *} \mathrm{p}<0.01$ and ${ }^{* * *} \mathrm{p}<0.001$, N.S. meant no significance.

we analyzed Bax and Bcl-2 expression in cytosolic and mitochondrial fractions. OGD/R injury markedly promoted the translocation of Bax from cytosol to mitochondria. $\mathrm{OA}-\mathrm{NO}_{2}$ pretreatment inhibited this process with no discernible change in the protein level of Bcl-2 (Fig. 5A). OA- $\mathrm{NO}_{2}$ significantly decreased the subsequent mitochondrial cytochrome $\mathrm{c}$ and AIF leakage caused by OGD/R injury (Fig. 5B).

In addition, we co-localized Bax with mitochondria, using active Bax to confirm the effect of $\mathrm{OA}-\mathrm{NO}_{2}$ on Bax activation. The $6 \mathrm{~A} 7$ monoclonal antibody recognized only the activated/proapoptotic form of Bax [29], which was stained red with Rhodamine (TRITC). Mitochondria were labeled with Mito-tracker green. In normal culture conditions, the 6A7 staining was almost undetectable, while OGD/R injury increased active Bax immunoreactivity. Moreover, the $6 \mathrm{~A} 7$ staining often coincided with the condensed and/or fragmented chromatin. $\mathrm{OA}-\mathrm{NO}_{2}$ significantly reduced the conformational activation of Bax and the apoptotic morphological changes of the nuclei (Fig. 6). These data indicated that $\mathrm{OA}^{-\mathrm{NO}_{2}}$ attenuated OGD/R-induced apoptosis via inhibiting Bax mitochondrial translocation and activation.

$\mathrm{OA}-\mathrm{NO}_{2}$ restored Akt and Gsk $3 \beta$ phosphorylation in $\mathrm{OGD} / \mathrm{R}$ injury

We evaluated whether Akt activation was involved in the protection of OA- $\mathrm{NO}_{2}$. OGD/R injury dramatically decreased Akt phosphorylation $(\mathrm{p}<0.001)$ without altering total Akt content, whereas $\mathrm{OA}-\mathrm{NO}_{2}$ normalized the Ser473 phosphorylated Akt level. OA- $\mathrm{NO}_{2}$ also preserved Ser9 phosphorylation of Gsk $3 \beta$, an Akt substrate [31,32] after OGD/R injury (Fig. 7). 


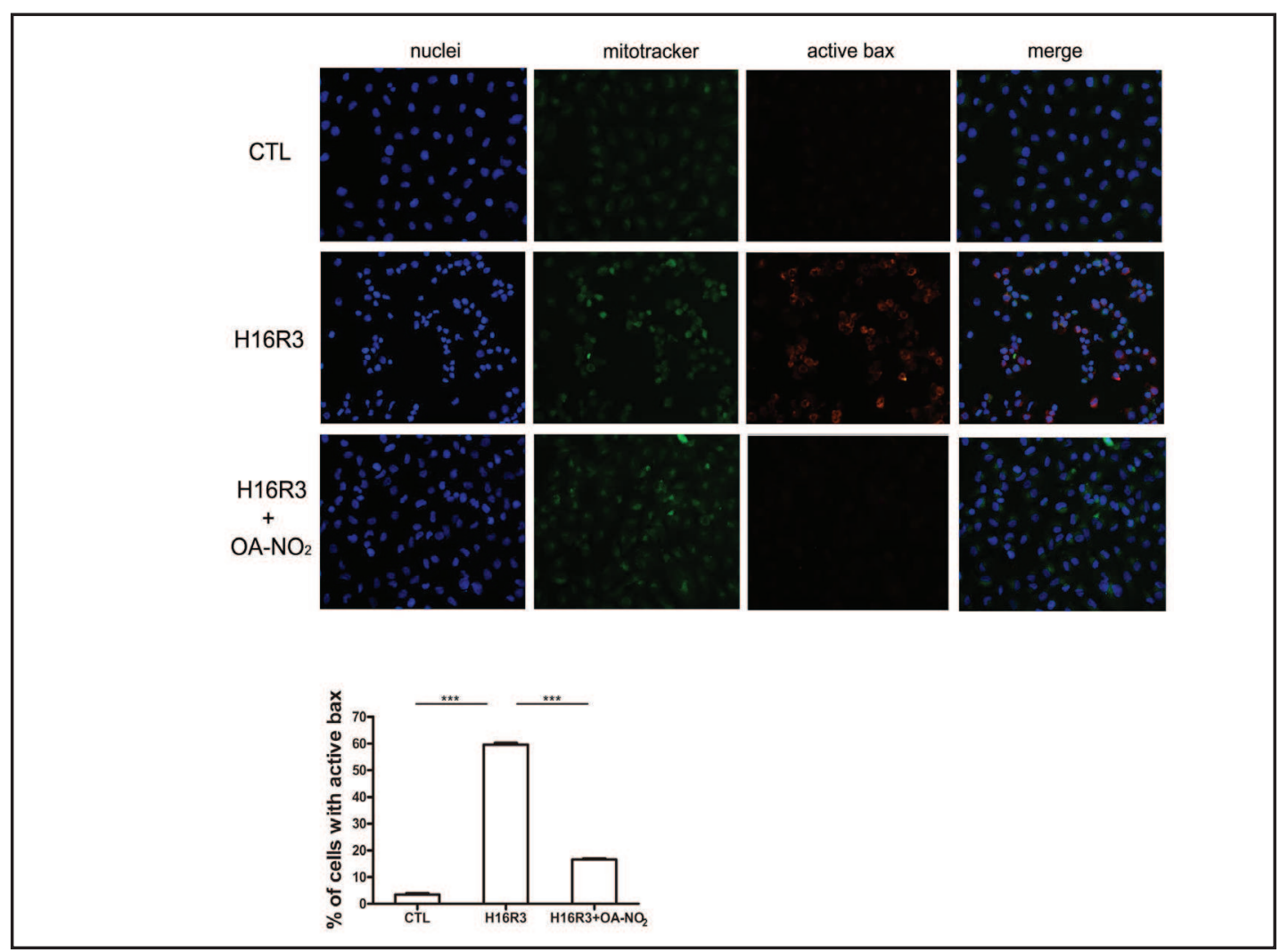

Fig. 6. $\mathrm{OA}-\mathrm{NO}_{2}$ inhibited $\mathrm{OGD} / \mathrm{R}$ induced Bax activation. Confluent HK-2 cells were subjected to OGD for $16 \mathrm{~h}$ followed by $3 \mathrm{~h}$ re-oxygenation period (H16R3) with or without $\mathrm{OA}-\mathrm{NO}_{2}(1.25 \mu \mathrm{M})$ pretreatment. Colocalization of active Bax (red) and Mitochondria (green) was visualized by fluorescence microscope using the 6A7 monoclonal antibody and Mito-tracker Green; nuclei were stained with DAPI (blue). Magnification: $\mathrm{x} 200$. Active Bax immunoreactivity was quantitated in $\sim 300$ cells per condition per experiment. Each assay was representative of three independent experiments. Data were shown as means $\pm \mathrm{SEM} ;{ }^{* * *} \mathrm{p}<0.001$.

GW9662 and PPAR- $\gamma$ siRNA abolished the protective effects of $\mathrm{OA}-\mathrm{NO}_{2}$ against $\mathrm{OGD} / \mathrm{R}$ induced injury

To evaluate the role of PPAR- $\gamma$ in OA- $\mathrm{NO}_{2}$-mediated cyto-protection, the specific PPAR- $\gamma$ antagonist GW9662 (Fig. 8A, B and C) and PPAR- $\gamma$ siRNA (Fig. 8D, E and F) were studied. The PPAR- $\gamma$ siRNA successfully suppressed PPAR- $\gamma$ protein expression by $55 \%$ (Fig. 8D) and induced a slight reduction in cell proliferation, compared to the control siRNA. Neither GW9662 nor PPAR- $\gamma$ siRNA/control siRNA affected the apoptotic rate of cell under normoxia (Fig. 8C, F). However, the protective effects of $\mathrm{OA}-\mathrm{NO}_{2}$ were completely abolished after pretreatment with GW9662 for $1 \mathrm{~h}$ or infection with PPAR- $\gamma$ siRNA before the OGD/R assay, as indicated by declined cell viability (Fig. 8B, E) and increased apoptosis (Fig. 8C, F). Moreover, GW9662 or PPAR- $\gamma$ siRNA largely eliminated the action of $\mathrm{OA}-\mathrm{NO}_{2}$ on phosphorylated Akt and Gsk $3 \beta$. Meanwhile, similar profiles were observed in apoptotic biomarkers (Fig. 9A, B). Taken together, these data suggested that $\mathrm{OA}-\mathrm{NO}_{2}$ exerted its anti-apoptotic effects via a PPAR- $\gamma$-dependent mechanism.

GW9662 and PPAR- $\gamma$ siRNA eliminated the suppression of OA-NO ${ }_{2}$ on Bax activation

To confirm that suppression of Bax activation by $\mathrm{OA}-\mathrm{NO}_{2}$ was also mediated via PPAR- $\gamma$, HK-2 cells were pre-incubated with GW9662 for $1 \mathrm{~h}$ or transfected with PPAR- $\gamma$ siRNA/ control siRNA and then subjected to the standard OGD/R assay. Active Bax was barely detected in $\mathrm{OA}-\mathrm{NO}_{2}$ - or/and GW9662-, PPAR- $\gamma$ siRNA- or control siRNA-treated cells under normal culture conditions. However, Bax was activated intensively upon OGD/R induction in

\section{KARGER}




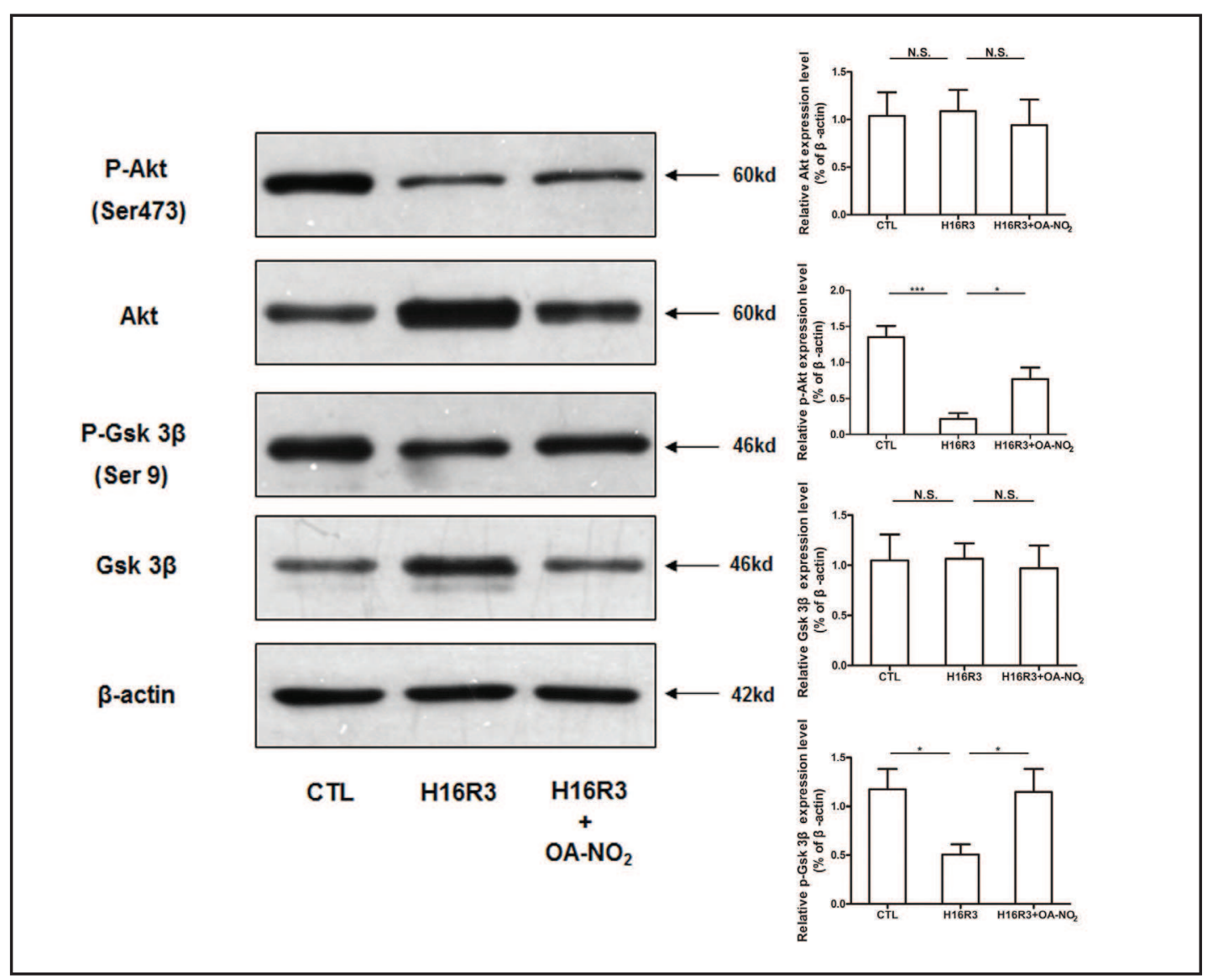

Fig. 7. $\mathrm{OA}-\mathrm{NO}_{2}$ preserved the phosphorylation of Akt and Gsk $3 \beta$ after OGD/R. Confluent HK-2 cells were subjected to OGD for $16 \mathrm{~h}$ followed by $3 \mathrm{~h}$ re-oxygenation period (H16R3) with or without OA- $\mathrm{NO}_{2}(1.25 \mu \mathrm{M})$ pretreatment. Akt and Gsk $3 \beta$ phosphorylation were examined by western blotting. Each assay was representative of three independent experiments. ${ }^{*} \mathrm{p}<0.05$ and ${ }^{* * *} \mathrm{p}<0.001$, N.S. meant no significance.

cells pre-incubated with GW9662 or transfected with PPAR- $\gamma$ siRNA in the presence of OA$\mathrm{NO}_{2}$ after 16h-OGD followed by 3h-re-oxygenation (Fig. 10). Additionally, the PPAR- $\gamma$ siRNA itself induced more intense activation of Bax after OGD/R injury, compared to control siRNA $(\mathrm{p}<0.05)$ (Fig. 10B). This demonstrated that endogenous PPAR- $\gamma$ played a vital role in OA$\mathrm{NO}_{2}$-mediated inhibition of Bax conformational activation.

\section{Discussion}

Nitrated unsaturated fatty acids are a novel series of NO•-derived anti-inflammatory and anti-oxidative lipid signaling molecules and have potent therapeutic benefits in acute tubular injury of different etiologies [24, 33, 34], while recent experimental evidence points to their therapeutic potential in directly promoting cell survival in cardiac ischemic infarction $[23,35,36]$. How $\mathrm{OA}-\mathrm{NO}_{2}$ modulates pro-survival signaling against renal ischemiareperfusion injury is not yet fully understood. In this study, we showed that $\mathrm{OA}^{-\mathrm{NO}_{2}}(1.25$ $\mu \mathrm{M}$ ) ameliorated OGD/R-induced apoptosis in HK-2 cells by inhibiting Bax mitochondrial translocation and thereby attenuating cytochrome $\mathrm{c}$ release and the subsequent caspase- 3 activation.

Although renal failure after ischemia has traditionally been attributed to acute tubular necrosis, it is now clear that necrosis fails to account for the severity of organ impairment, especially in humans [37]. This implicates cell apoptosis as a potential key participant in 


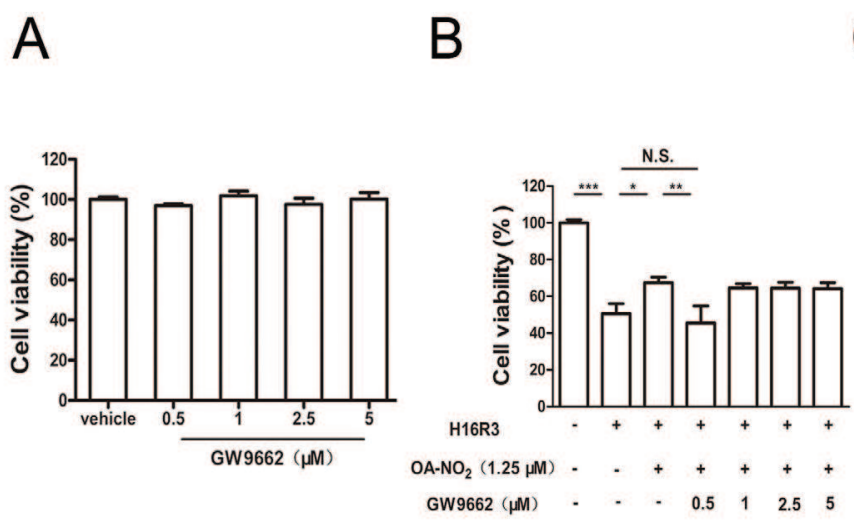

D

E
$\mathrm{C}_{(\mathrm{c} 1)}$

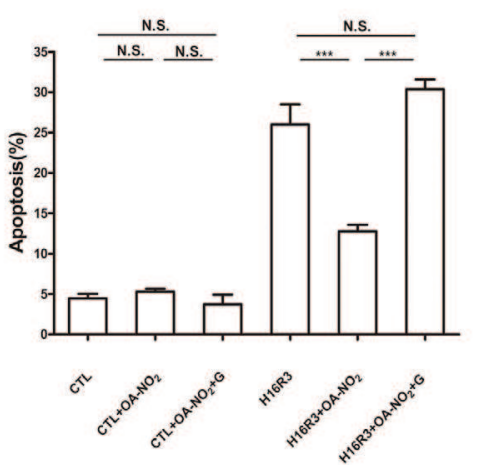

$F_{\text {(f1) }}$

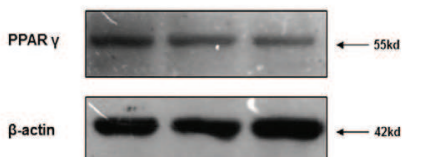

$\square \mathrm{CTL}$ H16R3 $\boxminus{\mathrm{OA}-\mathrm{NO}_{2}}$ $\square$ CTL $\square$ H16R3 目 OA-NO 2
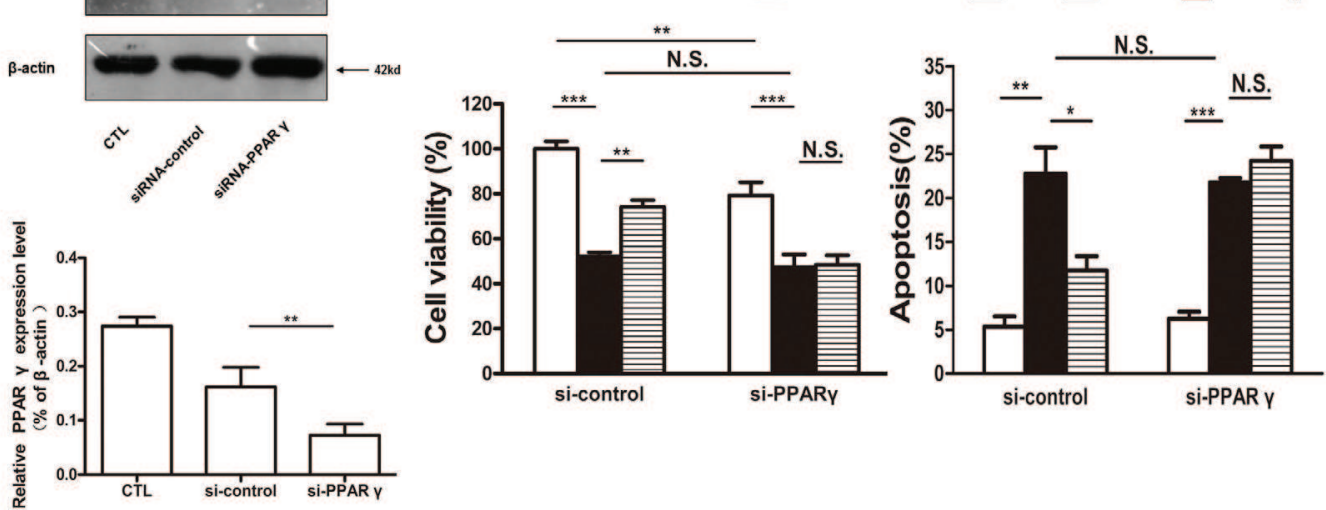

C

(c2)

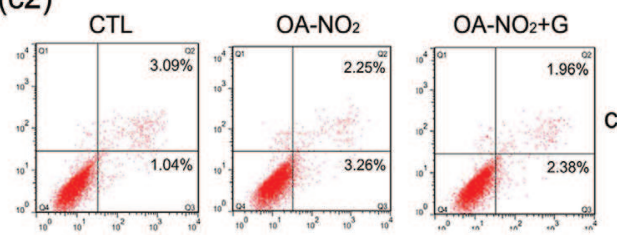

$\mathrm{F}$

(โ2)
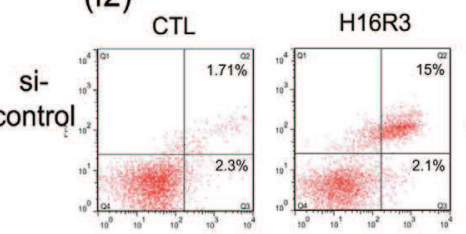

$\mathrm{H} 16 \mathrm{R} 3+\mathrm{OA}-\mathrm{NO}_{2}$

H16R3

$\mathrm{H} 16 \mathrm{R} 3+\mathrm{OA}-\mathrm{NO}_{2} \mathrm{H} 16 \mathrm{R} 3+\mathrm{OA}-\mathrm{NO}_{2}+\mathrm{G}$

CTL

H16R3

$\mathrm{H} 16 \mathrm{R} 3+\mathrm{OA}-\mathrm{NO}_{2}$
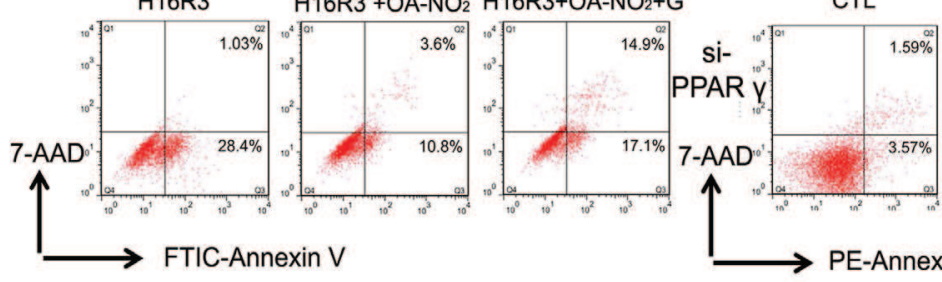

PE-Annexin V

Fig. 8. GW9662 and PPAR- $\gamma$ siRNA abolished the protective effects of $\mathrm{OA}-\mathrm{NO}_{2}$ against $\mathrm{OGD} / \mathrm{R}$ induced injury. A: Confluent HK-2 cells were treated with GW9662 (0.5-5 $\mu \mathrm{M})$ for $48 \mathrm{~h}$. Cytotoxicity of GW9662 was determined by CCK- 8 assay. D: Confluent HK-2 cells were exposed to PPAR- $\gamma$ siRNA/control siRNA. Protein contents were determined by western blotting. Confluent HK-2 cells treated with GW9662 (G) (0.5 $\mu \mathrm{M})$ or transfected with PPAR- $\gamma$ siRNA/control siRNA were subjected to OGD for $16 \mathrm{~h}$ followed by $3 \mathrm{~h}$ re-oxygenation period (H16R3) in the presence of $\mathrm{OA}-\mathrm{NO}_{2}(1.25 \mu \mathrm{M})$ or not. B, E: Viability was determined by CCK-8 assay. C, F: Apoptotic cells were analyzed by flow cytometry. Each assay was representative of three independent experiments. Data were shown as means \pm SEM; ${ }^{*} \mathrm{p}<0.05,{ }^{* *} \mathrm{p}<0.01$ and ${ }^{* * *} \mathrm{p}<0.001$, N.S. meant no significance. 


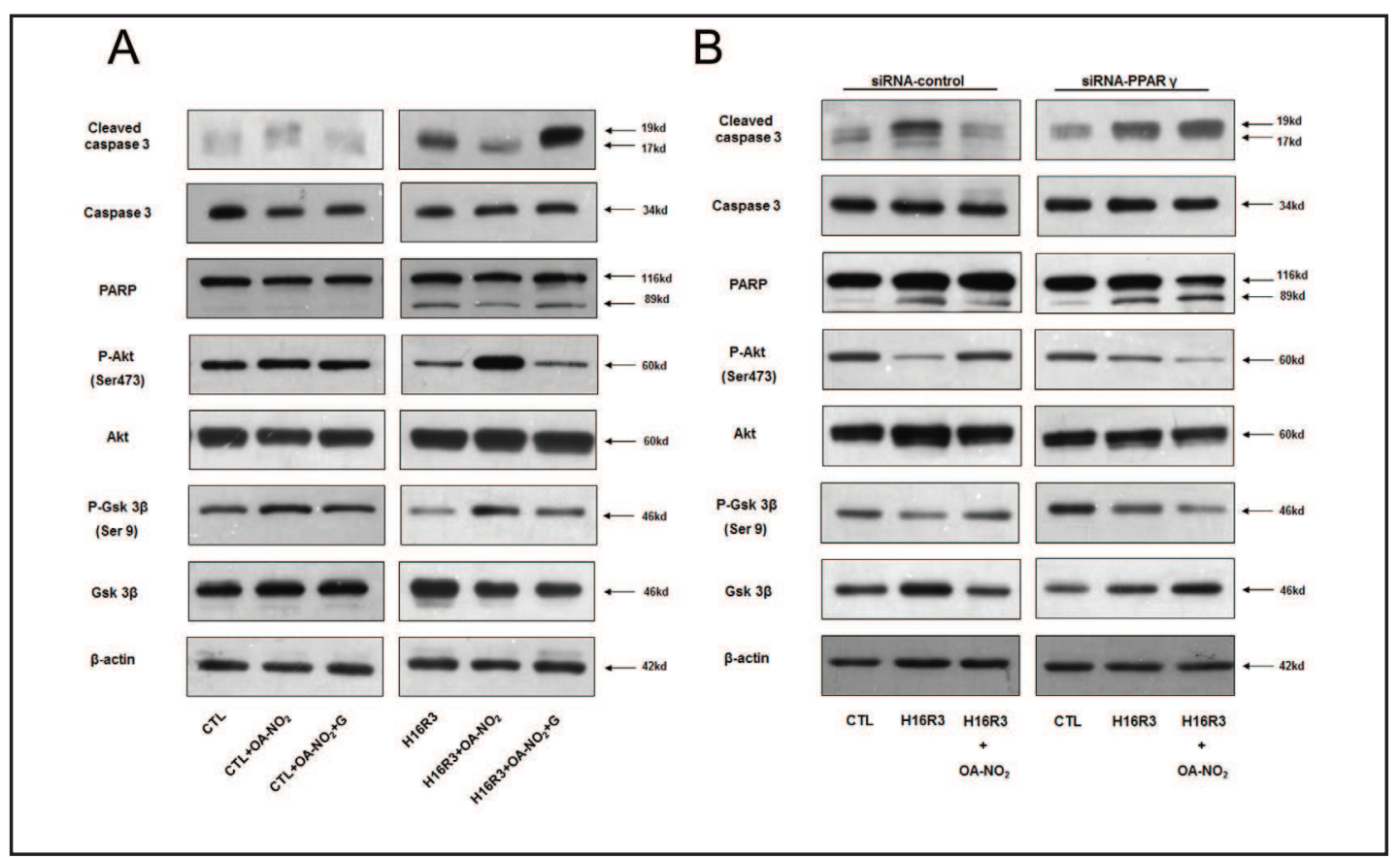

Fig. 9. GW9662 and PPAR- $\gamma$ siRNA negated the suppressive effects of $\mathrm{OA}-\mathrm{NO}_{2}$ against OGD/R induced Akt inhibition, Gsk $3 \beta$ and caspase-3 activation. Confluent HK-2 cells treated with GW9662 (G) (0.5 $\mu \mathrm{M})$ or transfected with PPAR- $\gamma$ siRNA/control siRNA were subjected to OGD for $16 \mathrm{~h}$ followed by $3 \mathrm{~h}$ re-oxygenation period (H16R3) in the presence of $\mathrm{OA}-\mathrm{NO}_{2}(1.25 \mu \mathrm{M})$ or not. Cleaved caspase-3, PARP expressions and Akt, Gsk $3 \beta$ phosphorylation were examined by western blotting. Each assay was representative of three independent experiments.

organ failure. The contribution of apoptosis to acute organ injury in previous experiments was confounded by the evanescent nature of apoptotic cells and the stochastic nature of the apoptotic process [4]. Despite these limitations, caspases were activated during renal ischemia and reperfusion [38] and caspase inhibitors reduced renal impairment [39], indicating the importance of apoptosis in ischemic renal failure. In this study, we showed that cell apoptosis played a prominent role in OGD/R injury, especially during the reoxygenation period (Fig. 2), as indicated by decreased cell viability (Fig. 3B), increased cell apoptosis (Fig. 4A), fragmented nuclei (Fig. 4B) and enhanced caspase-3 activity (Fig. $4 \mathrm{C}$ ), while pretreatment with $\mathrm{OA}-\mathrm{NO}_{2}$ significantly enhanced cell viability and inhibited apoptosis in HK-2 cells with OGD/R injury. Consistent with our observations, $\mathrm{NO}_{2}$-FA have been reported to induce mild uncoupling of mitochondria and to improve cardiomyocyte viability in isolated post-stimulate ischemia reperfusion cardiomyocytes [35]. Furthermore, long-term pretreatment with $\mathrm{OA}-\mathrm{NO}_{2}$ reduces myocardial infarct size and the density and distribution of TUNEL-positive cells within the area at risk in mice subjected to 30 min of myocardial ischemia and $24 \mathrm{~h}$ of in vivo reperfusion [23]. $\mathrm{NO}_{2}$-FA also afford acute protection against I/R injury at the isolated heart level via ANT1-Cys ${ }^{57}$ nitroalkylation [36]. However, others have reported pro-apoptotic actions of $\mathrm{NO}_{2}$-FA. $\mathrm{NO}_{2}$-FA were reported to induce rat aortic smooth muscle cell apoptosis via activation of caspase-dependent pathways [40] and to robustly stimulate neutrophil apoptosis in pulmonary allergic inflammation [12]. The basis for these opposite actions of $\mathrm{NO}_{2}$-FA is unclear, but several sources of variations such as cell types, experimental conditions, and concentrations of the ligands may account for the discrepant observations between the present study and previous reports. In this study, OA$\mathrm{NO}_{2}$ at relatively low concentrations $(0.5-1.25 \mu \mathrm{M})$ was protective [35] (Fig. 3), while at higher concentrations ( $>5 \mu \mathrm{M})$, it was pro-apoptotic in cultured cells [40]. This might be due to the potential toxicity of this compound at high doses. In summary, this study demonstrates for 


\section{Cellular Physiology $\quad$ Cell Physiol Biochem 2015;35:1201-1218 \begin{tabular}{l|l|l|} 
DOI: 10.1159/000373944 & O 2015 S. Karger AG, Basel
\end{tabular} and Biochemistry Published onine: February 10, $2015 \quad$ www.karger.com/cpb

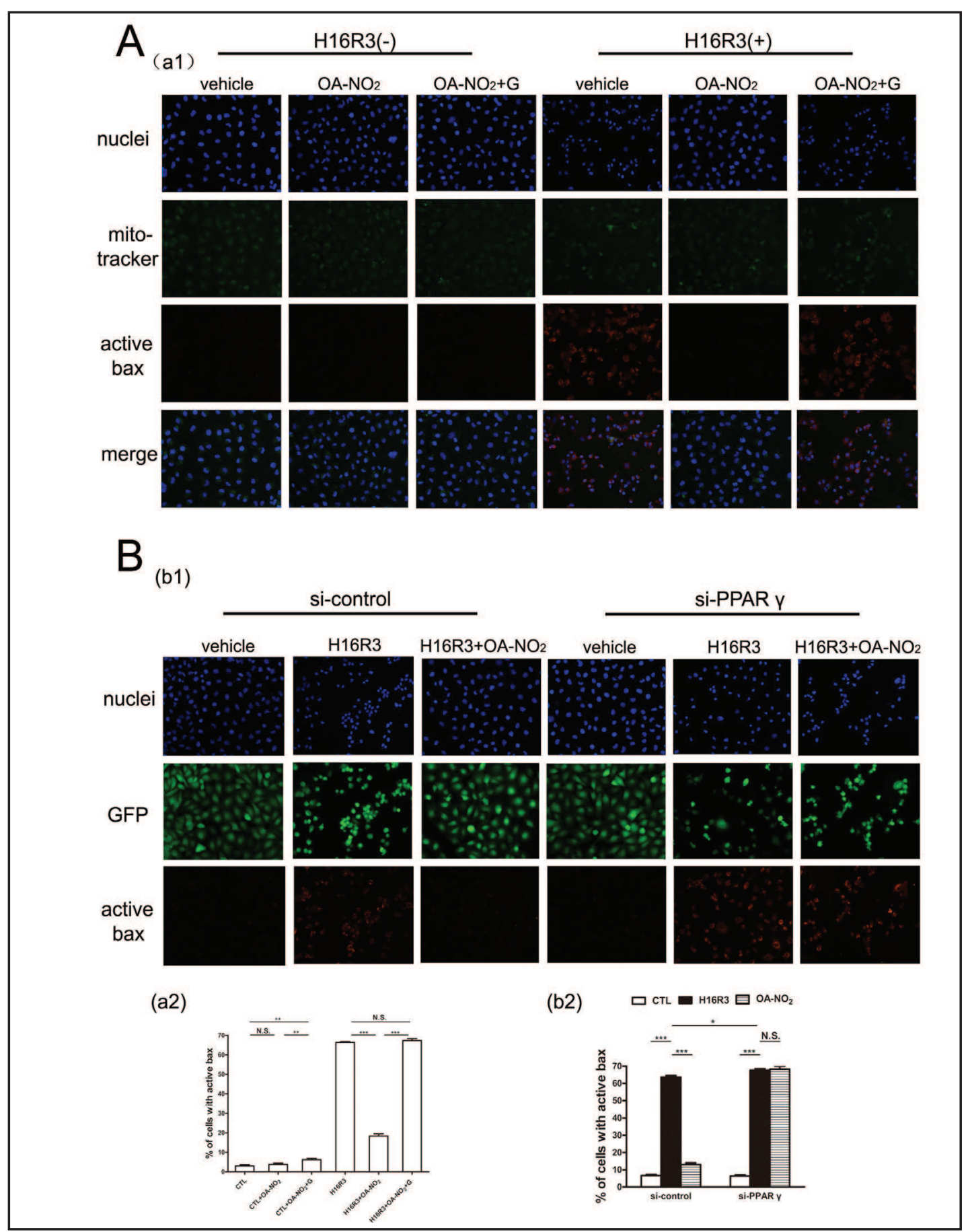

Fig. 10. GW9662 and PPAR- $\gamma$ siRNA eliminated the suppression of $\mathrm{OA}-\mathrm{NO}_{2}$ on Bax activation. Confluent HK-2 cells treated with GW9662 (G) $(0.5 \mu \mathrm{M})$ or transfected with PPAR- $\gamma$ siRNA/control siRNA were subjected to OGD for $16 \mathrm{~h}$ followed by $3 \mathrm{~h}$ re-oxygenation period (H16R3) in the presence of OA-NO ${ }_{2}(1.25$ $\mu \mathrm{M}$ ) or not. A: Co-localization of active Bax (red) and Mitochondria (green) was visualized by fluorescence microscope using the 6A7 monoclonal antibody and Mito-tracker Green in un-transfected cells; nuclei were stained with DAPI (blue). Magnification: x 200. B: Mitochondrial active Bax (red), cellular shrinkage (green) and nuclei (blue) were detected by fluorescence microscope in PPAR- $\gamma$ siRNA/control siRNA transfected cells. Magnification: x 200. (a2, b2) showed active Bax immunoreactivity quantitated in 300 cells per condition per experiment. Each assay was representative of three independent experiments. Data were shown as means \pm SEM; ${ }^{*} p<0.05,{ }^{* *} p<0.01$ and ${ }^{* * *} p<0.001$, N.S. meant no significance.

\section{KARGER}


Fig. 11. Possible mechanism of $\mathrm{OA}-\mathrm{NO}_{2}-$ mediated cyto-protection against OGD/R induced apoptosis was shown. In the schematic diagram, activation pathways were indicated by $(\rightarrow)$, and the inhibitory pathways were indicated by $(-1)$.

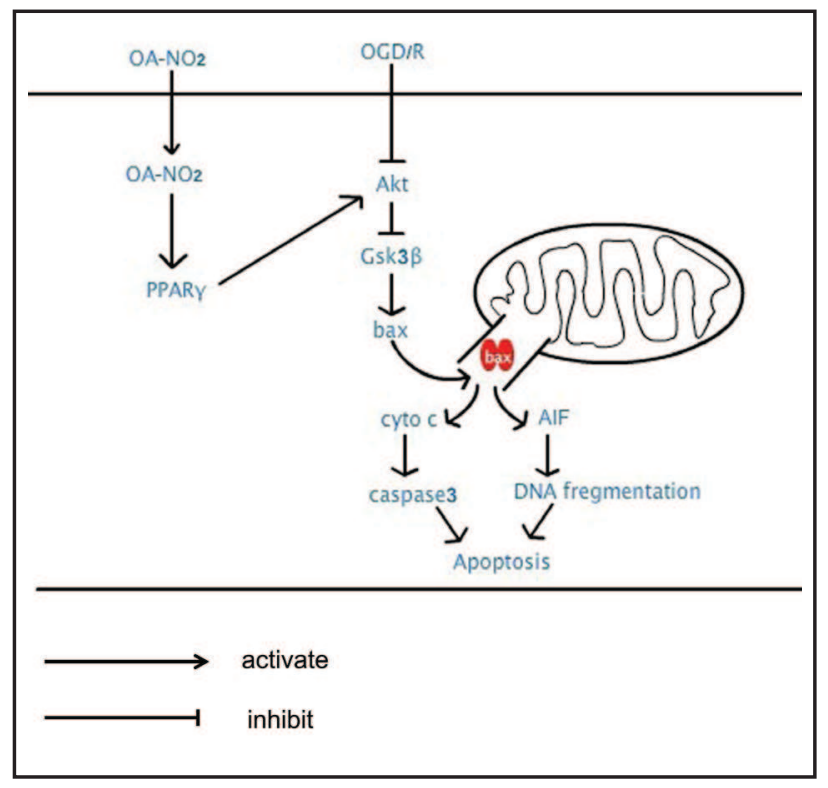

the first time that $\mathrm{OA}-\mathrm{NO}_{2}(1.25 \mu \mathrm{M})$ possesses anti-apoptotic effects against OGD/R injury in HK-2 cells.

How does OA- $\mathrm{NO}_{2}$ ameliorate apoptosis? Mitochondrial Outer Membrane Permeabilization (MOMP) is the decisive event that delimits the frontier between survival and death upon apoptosis induction, and Bax mitochondrial translocation initiates this process $[41,42]$. Bax resides predominantly in the cytosol, where it shifts from a cytosol-soluble to membrane-bound form and forms homooligomeric pores or opens existing mitochondrial membrane channels, resulting in MOMP upon apoptosis induction [30, 42, 43]. This leads to the leakage of mitochondrial cytochrome $\mathrm{c}$ and AIF and subsequent caspase-dependent or -independent apoptosis [30, 42, 44]. In our study, pre-incubation with $\mathrm{OA}-\mathrm{NO}_{2}$ markedly reduced Bax activation (Fig. 6), leakage of pro-apoptotic factors and subsequent caspase-3 activation caused by OGD/R injury (Fig. 5), and increased cell viability (Fig. 3B) in a pattern similar to that reported previously [45]. In contrast, $\mathrm{OA}-\mathrm{NO}_{2}$ failed to induce a discernible change in the protein levels of Bcl-2 in cytosolic or mitochondrial fraction (Fig. 5A). This suggests that $\mathrm{OA}-\mathrm{NO}_{2}$ may modulate the action of the Bcl-2 family by regulating their posttranslational modification rather than influencing protein levels. Bax can be regulated by the altered activity of kinases such as Akt and/or Gsk $3 \beta[29,41,46]$. Growth factor withdrawal and ATP depletion inactivate Akt, resulting in the activation of Gsk $3 \beta$ [32], which activates Bax by phosphorylating Ser163 and drives Bax to mitochondria $[29,41]$. Interestingly, Gardai et al. proved that Bax could also be phosphorylated at Ser184 by Akt, promoting its heterodimerization with anti-apoptotic Bcl-2 family members and maintaining its localization in the cytosol [46]. Thus, Bax activation during metabolic stress would be favored by the combined inactivation of Akt and activation of Gsk $3 \beta$. In support of this concept, Bax activity was found to be regulated by the $\mathrm{OA}-\mathrm{NO}_{2}$-mediated phosphorylation of Akt and Gsk $3 \beta$ in the present study. First, stress contemporaneously inactivated Akt and activated Gsk $3 \beta$ (Fig. 7) and Bax (Fig. 6). Second, OA-NO ${ }_{2}$ promoted Akt activation and inhibited Gsk $3 \beta$ and Bax activation. Third, inactivation of the Akt pathway caused by PPAR- $\gamma$ inhibition completely eliminated the regulatory effects of OA-NO ${ }_{2}$ on Akt, Gsk $3 \beta$ (Fig. 9A, B) and Bax (Fig. 10A, B). All these data further confirm that the $\mathrm{OA}-\mathrm{NO}_{2}$ abolishes Bax activation through regulating Akt and Gsk $3 \beta$ phosphorylation.

Peroxisome proliferator-activated receptor $\gamma$ (PPAR- $\gamma$ ) is a member of the nuclear receptor superfamily of transcription factors involved in the regulation of vital processes such as inflammation, proliferation, migration, matrix remodeling, differentiation and metabolic functions $[47,48]$. Ligands for PPAR- $\gamma$ include natural compounds such as eicosanoids, oxidized phospholipids, 15 -deoxy- $\Delta 12,14-\mathrm{PGJ} 2$ and drugs such as the thiazolidinedione 


\section{Cellular Physiology and Biochemistry}

Cell Physiol Biochem 2015;35:1201-1218

Nie et al.: OA-NO $\mathrm{N}_{2}$ Inhibits Apoptosis via PPAR- $\gamma$

derivative rosiglitazone [8], and have been reported to ameliorate ischemia and reperfusion injury in a PPAR- $\gamma$ dependent manner. The PPAR- $\gamma$ antagonist, bisphenol A diglycidyl ether (BADGE) abolishes the protection afforded by rosiglitazone and 15d-PGJ2 in a rat model of intestinal I/R [49]. Moreover, rosiglitazone $(10 \mathrm{mg} / \mathrm{kg})$ inhibits stomach I/R injury in the heterozygous PPAR- $\gamma$-deficient mice, even via activation of reduced levels of PPAR- $\gamma$ [50]. Since $\mathrm{NO}_{2}$-FA act as partial agonists of PPAR- $\gamma$ and covalently modified PPAR- $\gamma$ by S-nitroalkylation at Cys285 [20,51], we therefore suggest that the protection observed here was mediated largely via PPAR- $\gamma$. Consistent with these findings, PPAR- $\gamma$ siRNA and GW 9662 eliminated the beneficial effects afforded by OA- $\mathrm{NO}_{2}$ (Fig. 8, 10). Furthermore, they abolished the restoration of Akt and Gsk $3 \beta$ phosphorylation exerted by $\mathrm{OA}-\mathrm{NO}_{2}$ during OGD/R injury (Fig. 9).

How PPAR- $\gamma$ regulates Akt activity is presently unclear, even if rosiglitazone has been suggested to activate Akt in a PPAR- $\gamma$-dependent way $[28,52,53]$. PPAR- $\gamma$ might indirectly modulate Akt activation by increasing the expression of HSP27 [54]. HSP27, in turn, promotes Akt activation and inhibits Bax mitochondrial translocation [45]. However, whether the increase of HSP 27 is due to PPAR- $\gamma$-activation-induced transcription deserves further study. Alternatively, $\mathrm{NO}_{2}$-FA have been reported to regulate cell signaling by a covalent and reversible posttranslational modification (nitroalkylation) of key signaling proteins, such as the p65 subunit of nuclear factor $\kappa B[10,11]$ in a PPAR- $\gamma$-independent manner. Thiol residues of proteins are highly susceptible nucleophilic targets of electrophile reactions, with nitroalkylation frequently altering protein structure and function [55]. Protein-tyrosine phosphatases contain an active site motif that includes an invariant Cys with a low $\mathrm{pK}_{\mathrm{a}}$ value, a property that promotes nucleophilic reactivity and susceptibility to nitroalkylation [56]. Thus $\mathrm{NO}_{2}$-FA might regulate Akt activity via nitroalkylation of protein-tyrosine phosphatases, but this remains to be determined and will be the subject of our future investigations.

In conclusion, our study clearly demonstrates that pretreatment of the post-OGD/R renal tubular cells with $\mathrm{OA}-\mathrm{NO}_{2}$ results in the attenuation of ischemia and reperfusioninduced apoptosis. The protective effects of $\mathrm{OA}-\mathrm{NO}_{2}$ were attributed to a combination of Akt activation, Gsk $3 \beta$ inhibition, Bax inactivation and subsequent suppression of mitochondriamediated apoptotic cascade in a PPAR- $\gamma$-dependent manner (Fig. 11). This study also demonstrated for the first time that $\mathrm{OA}-\mathrm{NO}_{2}$ protects against renal ischemia-reperfusion injury by directly modulating mitochondria-mediated apoptosis. Future investigations will be necessary to determine the mechanism of Akt activation by $\mathrm{NO}_{2}$-FA. Our findings suggest a novel application for $\mathrm{NO}_{2}$-FA in the treatment of ischemia and/or reperfusion injury in myocardial infarction, organ transplantation and ischemic stroke in the future.

\section{Acknowledgements}

This work is supported by National Natural Science Foundation of China (N0.81100509) and Promotive research fund for excellent young and middle-aged scientists of Shandong Province (NO. BS2011YY009).

\section{Disclosure Statement}

None.

\section{References}

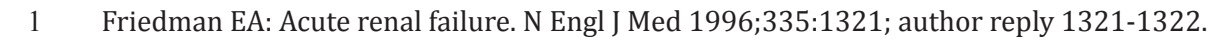

- Eltzschig HK, Eckle T: Ischemia and reperfusion--from mechanism to translation. Nat Med 2011;17:13911401.
} 


\section{Cellular Physiology and Biochemistry}

Cell Physiol Biochem 2015;35:1201-1218

\begin{tabular}{l|l}
\hline DOI: $10.1159 / 000373944$ & (C) 2015 S. Karger AG, Basel
\end{tabular}

Published onlıne: February 10, $2015 \quad$ www.karger.com/cpb

Nie et al.: OA-NO $\mathrm{N}_{2}$ Inhibits Apoptosis via PPAR- $\gamma$

-3 Yousefipour Z, Oyekan A, Newaz M: Interaction of oxidative stress, nitric oxide and peroxisome proliferator activated receptor gamma in acute renal failure. Pharmacol Ther 2010;125:436-445.

4 Bonegio R, Lieberthal W: Role of apoptosis in the pathogenesis of acute renal failure. Curr Opin Nephrol Hypertens 2002;11:301-308.

-5 Wolfs TG, de Vries B, Walter SJ, Peutz-Kootstra CJ, van Heurn LW, Oosterhof GO, Buurman WA: Apoptotic cell death is initiated during normothermic ischemia in human kidneys. Am J Transplant 2005;5:68-75.

6 Nakajima A, Wada K, Miki H, Kubota N, Nakajima N, Terauchi Y, Ohnishi S, Saubermann LJ, Kadowaki T, Blumberg RS,Nagai R, Matsuhashi H: Endogenous PPAR gamma mediates anti-inflammatory activity in murine ischemia-reperfusion injury. Gastroenterology 2001;120:460-469.

7 Yasuda S, Kobayashi H, Iwasa M, Kawamura I, Sumi S, Narentuoya B, Yamaki T, Ushikoshi H, Nishigaki K, Nagashima K, Takemura G, Fujiwara T, Fujiwara H, Minatoguchi S: Antidiabetic drug pioglitazone protects the heart via activation of PPAR-gamma receptors, PI3-kinase, Akt, and eNOS pathway in a rabbit model of myocardial infarction. Am J Physiol Heart Circ Physiol 2009;296:H1558-1565.

$\rightarrow 8$ Fong WH, Tsai HD, Chen YC, Wu JS, Lin TN: Anti-apoptotic actions of PPAR-gamma against ischemic stroke. Mol Neurobiol 2010;41:180-186.

9 Doi S, Masaki T, Arakawa T, Takahashi S, Kawai T, Nakashima A, Naito T, Kohno N, Yorioka N: Protective effects of peroxisome proliferator-activated receptor gamma ligand on apoptosis and hepatocyte growth factor induction in renal ischemia-reperfusion injury. Transplantation 2007;84:207-213.

10 Freeman BA, Baker PR, Schopfer FJ, Woodcock SR, Napolitano A, d'Ischia M: Nitro-fatty acid formation and signaling. J Biol Chem 2008;283:15515-15519.

11 Cui T, Schopfer FJ, Zhang J, Chen K, Ichikawa T, Baker PR, Batthyany C, Chacko BK, Feng X, Patel RP, Agarwal A, Freeman BA, Chen YE: Nitrated fatty acids: Endogenous anti-inflammatory signaling mediators. J Biol Chem 2006;281:35686-35698.

12 Reddy AT, Lakshmi SP, Dornadula S, Pinni S, Rampa DR, Reddy RC: The nitrated fatty acid 10-nitro-oleate attenuates allergic airway disease. J Immunol 2013;191:2053-2063.

13 Ichikawa T, Zhang J, Chen K, Liu Y, Schopfer FJ, Baker PR, Freeman BA, Chen YE, Cui T: Nitroalkenes suppress lipopolysaccharide-induced signal transducer and activator of transcription signaling in macrophages: a critical role of mitogen-activated protein kinase phosphatase 1 . Endocrinology 2008;149:4086-4094.

-14 Iles KE, Wright MM, Cole MP, Welty NE, Ware LB, Matthay MA, Schopfer FJ, Baker PR, Agarwal A, Freeman BA: Fatty acid transduction of nitric oxide signaling: nitrolinoleic acid mediates protective effects through regulation of the ERK pathway. Free Radic Biol Med 2009;46:866-875.

15 Wright MM, Schopfer FJ, Baker PR, Vidyasagar V, Powell P, Chumley P, Iles KE, Freeman BA, Agarwal A: Fatty acid transduction of nitric oxide signaling: nitrolinoleic acid potently activates endothelial heme oxygenase 1 expression. Proc Natl Acad Sci U S A 2006;103:4299-4304.

-16 Khoo NK, Rudolph V, Cole MP, Golin-Bisello F, Schopfer FJ, Woodcock SR, Batthyany C, Freeman BA: Activation of vascular endothelial nitric oxide synthase and heme oxygenase-1 expression by electrophilic nitro-fatty acids. Free Radic Biol Med 2010;48:230-239.

-17 Kansanen E, Jyrkkanen HK, Volger OL, Leinonen H, Kivela AM, Hakkinen SK, Woodcock SR, Schopfer FJ, Horrevoets AJ, Yla-Herttuala S, Freeman BA, Levonen AL: Nrf2-dependent and -independent responses to nitro-fatty acids in human endothelial cells: identification of heat shock response as the major pathway activated by nitro-oleic acid. J Biol Chem 2009;284:33233-33241.

18 Schopfer FJ, Lin Y, Baker PR, Cui T, Garcia-Barrio M, Zhang J, Chen K, Chen YE, Freeman BA: Nitrolinoleic acid: an endogenous peroxisome proliferator-activated receptor gamma ligand. Proc Natl Acad Sci U S A 2005;102:2340-2345.

-19 Baker PR, Lin Y, Schopfer FJ, Woodcock SR, Groeger AL, Batthyany C, Sweeney S, Long MH, Iles KE, Baker LM, Branchaud BP, Chen YE, Freeman BA: Fatty acid transduction of nitric oxide signaling: multiple nitrated unsaturated fatty acid derivatives exist in human blood and urine and serve as endogenous peroxisome proliferator-activated receptor ligands. J Biol Chem 2005;280:42464-42475.

20 Schopfer FJ, Cole MP, Groeger AL, Chen CS, Khoo NK, Woodcock SR, Golin-Bisello F, Motanya UN, Li Y, Zhang J , Garcia-Barrio MT, Rudolph TK, Rudolph V, Bonacci G, Baker PR, Xu HE, Batthyany CI, Chen YE, Hallis TM, Freeman BA: Covalent peroxisome proliferator-activated receptor gamma adduction by nitro-fatty acids: selective ligand activity and anti-diabetic signaling actions. J Biol Chem 2010;285:12321-12333. 


\section{Cellular Physiology and Biochemistry}

Cell Physiol Biochem 2015;35:1201-1218

\begin{tabular}{l|l}
\hline DOI: $10.1159 / 000373944$ & (C) 2015 S. Karger AG, Basel
\end{tabular}

Published onlıne: February 10, $2015 \quad$ www.karger.com/cpb

Nie et al.: $\mathrm{OA}-\mathrm{NO}_{2}$ Inhibits Apoptosis via PPAR- $\gamma$

21 Reddy AT, Lakshmi SP, Reddy RC: The Nitrated Fatty Acid 10-Nitro-oleate Diminishes Severity of LPSInduced Acute Lung Injury in Mice. PPAR Res 2012;2012:617063.

-22 Borniquel S, Jansson EA, Cole MP, Freeman BA, Lundberg JO: Nitrated oleic acid up-regulates PPARgamma and attenuates experimental inflammatory bowel disease. Free Radic Biol Med 2010;48:499-505.

-23 Rudolph V, Rudolph TK, Schopfer FJ, Bonacci G, Woodcock SR, Cole MP, Baker PR, Ramani R, Freeman BA: Endogenous generation and protective effects of nitro-fatty acids in a murine model of focal cardiac ischaemia and reperfusion. Cardiovasc Res 2010;85:155-166.

-24 Liu H, Jia Z, Soodvilai S, Guan G, Wang MH, Dong Z, Symons JD, Yang T: Nitro-oleic acid protects the mouse kidney from ischemia and reperfusion injury. Am J Physiol Renal Physiol 2008;295:F942-949.

25 Modis K, Gero D, Nagy N, Szoleczky P, Toth ZD, Szabo C: Cytoprotective effects of adenosine and inosine in an in vitro model of acute tubular necrosis. Br J Pharmacol 2009;158:1565-1578.

26 Szoleczky P, Modis K, Nagy N, Dori Toth Z, DeWitt D, Szabo C, Gero D: Identification of agents that reduce renal hypoxia-reoxygenation injury using cell-based screening: purine nucleosides are alternative energy sources in LLC-PK1 cells during hypoxia. Arch Biochem Biophys 2012;517:53-70.

27 Saenz-Morales D, Conde E, Escribese MM, Garcia-Martos M, Alegre L, Blanco-Sanchez I, Garcia-Bermejo ML: ERK1/2 mediates cytoskeleton and focal adhesion impairment in proximal epithelial cells after renal ischemia. Cell Physiol Biochem 2009;23:285-294.

28 Wu JS, Lin TN, Wu KK: Rosiglitazone and PPAR-gamma overexpression protect mitochondrial membrane potential and prevent apoptosis by upregulating anti-apoptotic Bcl-2 family proteins. J Cell Physiol 2009;220:58-71.

-29 Linseman DA, Butts BD, Precht TA, Phelps RA, Le SS, Laessig TA, Bouchard RJ, Florez-McClure ML, Heidenreich KA: Glycogen synthase kinase-3beta phosphorylates Bax and promotes its mitochondrial localization during neuronal apoptosis. J Neurosci 2004;24:9993-10002.

-30 Kuwana T, Mackey MR, Perkins G, Ellisman MH, Latterich M, Schneiter R, Green DR, Newmeyer DD: Bid, Bax, and lipids cooperate to form supramolecular openings in the outer mitochondrial membrane. Cell 2002;111:331-342.

- 31 Cross DA, Alessi DR, Cohen P, Andjelkovich M, Hemmings BA: Inhibition of glycogen synthase kinase-3 by insulin mediated by protein kinase B. Nature 1995;378:785-789.

-32 Cross DA, Culbert AA, Chalmers KA, Facci L, Skaper SD, Reith AD: Selective small-molecule inhibitors of glycogen synthase kinase-3 activity protect primary neurones from death. J Neurochem 2001;77:94-102.

-33 Wang H, Liu H, Jia Z, Olsen C, Litwin S, Guan G, Yang T: Nitro-oleic acid protects against endotoxin-induced endotoxemia and multiorgan injury in mice. Am J Physiol Renal Physiol 2010;298:F754-762.

-34 Liu S, Jia Z, Zhou L, Liu Y, Ling H, Zhou SF, Zhang A, Du Y, Guan G, Yang T: Nitro-oleic acid protects against adriamycin-induced nephropathy in mice. Am J Physiol Renal Physiol 2013;305:F1533-1541.

-35 Nadtochiy SM, Baker PR, Freeman BA, Brookes PS: Mitochondrial nitroalkene formation and mild uncoupling in ischaemic preconditioning: implications for cardioprotection. Cardiovasc Res 2009;82:333340.

-36 Nadtochiy SM, Zhu Q, Urciuoli W, Rafikov R, Black SM, Brookes PS: Nitroalkenes confer acute cardioprotection via adenine nucleotide translocase 1. J Biol Chem 2012;287:3573-3580.

- 37 Rosen S, Heyman SN: Difficulties in understanding human "acute tubular necrosis": limited data and flawed animal models. Kidney Int 2001;60:1220-1224.

- 38 Shi Y, Melnikov VY, Schrier RW, Edelstein CL: Downregulation of the calpain inhibitor protein calpastatin by caspases during renal ischemia-reperfusion. Am J Physiol Renal Physiol 2000;279:F509-517.

-39 Daemen MA, van 't Veer C, Denecker G, Heemskerk VH, Wolfs TG, Clauss M, Vandenabeele P, Buurman WA: Inhibition of apoptosis induced by ischemia-reperfusion prevents inflammation. J Clin Invest 1999;104:541-549.

-40 Tang X, Guo Y, Nakamura K, Huang H, Hamblin M, Chang L, Villacorta L, Yin K, Ouyang H, Zhang J: Nitroalkenes induce rat aortic smooth muscle cell apoptosis via activation of caspase-dependent pathways. Biochem Biophys Res Commun 2010;397:239-244.

- 41 Wang Z, Havasi A, Gall J, Bonegio R, Li Z, Mao H, Schwartz JH, Borkan SC: GSK3beta promotes apoptosis after renal ischemic injury. J Am Soc Nephrol 2010;21:284-294.

-42 Kroemer G, Galluzzi L, Brenner C: Mitochondrial membrane permeabilization in cell death. Physiol Rev 2007;87:99-163. 


\section{Cellular Physiology and Biochemistry}

Cell Physiol Biochem 2015;35:1201-1218

\begin{tabular}{l|l}
\hline DOI: $10.1159 / 000373944$ & (c) 2015 S. Karger AG, Basel
\end{tabular}

Nie et al.: OA-NO $\mathrm{N}_{2}$ Inhibits Apoptosis via PPAR- $\gamma$

43 Hsu YT, Wolter KG, Youle RJ: Cytosol-to-membrane redistribution of Bax and Bcl-X(L) during apoptosis. Proc Natl Acad Sci U S A 1997;94:3668-3672.

44 Ravagnan L, Roumier T, Kroemer G: Mitochondria, the killer organelles and their weapons. J Cell Physiol 2002;192:131-137.

45 Havasi A, Li Z, Wang Z, Martin JL, Botla V, Ruchalski K, Schwartz JH, Borkan SC: Hsp27 inhibits Bax activation and apoptosis via a phosphatidylinositol 3-kinase-dependent mechanism. J Biol Chem 2008;283:12305-12313.

-46 Gardai SJ, Hildeman DA, Frankel SK, Whitlock BB, Frasch SC, Borregaard N, Marrack P, Bratton DL, Henson PM: Phosphorylation of Bax Ser184 by Akt regulates its activity and apoptosis in neutrophils. J Biol Chem 2004;279:21085-21095.

47 Ricote M, Li AC, Willson TM, Kelly CJ, Glass CK: The peroxisome proliferator-activated receptor-gamma is a negative regulator of macrophage activation. Nature 1998;391:79-82.

-48 van Bilsen M, van Nieuwenhoven FA: PPARs as therapeutic targets in cardiovascular disease. Expert Opin Ther Targets 2010;14:1029-1045.

49 Cuzzocrea S, Pisano B, Dugo L, Ianaro A, Patel NS, Di Paola R, Genovese T, Chatterjee PK, Di Rosa M, Caputi AP, Thiemermann C: Rosiglitazone and 15-deoxy-Delta12,14-prostaglandin J2, ligands of the peroxisome proliferator-activated receptor-gamma (PPAR-gamma), reduce ischaemia/reperfusion injury of the gut. Br J Pharmacol 2003;140:366-376.

-50 Wada K, Nakajima A, Takahashi H, Yoneda M, Fujisawa N, Ohsawa E, Kadowaki T, Kubota N, Terauchi Y, Matsuhashi N, Saubermann LJ, Nakajima N, Blumberg RS: Protective effect of endogenous PPARgamma against acute gastric mucosal lesions associated with ischemia-reperfusion. Am J Physiol Gastrointest Liver Physiol 2004;287:G452-458.

-51 Li Y, Zhang J, Schopfer FJ, Martynowski D, Garcia-Barrio MT, Kovach A, Suino-Powell K, Baker PR, Freeman BA, Chen YE, Xu HE: Molecular recognition of nitrated fatty acids by PPAR gamma. Nat Struct Mol Biol 2008;15:865-867.

-52 Kilter H, Werner M, Roggia C, Reil JC, Schafers HJ, Kintscher U, Bohm M: The PPAR-gamma agonist rosiglitazone facilitates Akt rephosphorylation and inhibits apoptosis in cardiomyocytes during hypoxia/ reoxygenation. Diabetes Obes Metab 2009;11:1060-1067.

-53 Morrison A, Yan X, Tong C, Li J: Acute rosiglitazone treatment is cardioprotective against ischemiareperfusion injury by modulating AMPK, Akt, and JNK signaling in nondiabetic mice. Am J Physiol Heart Circ Physiol 2011;301:H895-902.

-54 Yi JH, Park SW, Brooks N, Lang BT, Vemuganti R: PPARgamma agonist rosiglitazone is neuroprotective after traumatic brain injury via anti-inflammatory and anti-oxidative mechanisms. Brain Res 2008;1244:164172.

55 Batthyany C, Schopfer FJ, Baker PR, Duran R, Baker LM, Huang Y, Cervenansky C, Branchaud BP, Freeman BA: Reversible post-translational modification of proteins by nitrated fatty acids in vivo. J Biol Chem 2006;281:20450-20463.

-56 Barford D, Jia Z, Tonks NK: Protein tyrosine phosphatases take off. Nat Struct Biol 1995;2:1043-1053. 